Historic, Archive Document

Do not assume content reflects current scientific knowledge, policies, or practices. 





\section{Nursery Catalog \\ For the Season of 1913-1914}

PUBLISHED BY

\section{TheLuther Burbank Company}

Seeds - Plants - Trees

Sole Distributer of the Burbank Horticultural Productions

Successor to

LUTHER BURBANK

General OfFices

SECOND FLOOR BURBANK BUILDING

MARKET AND BEALE STREETS

San Francisco, California, U. S. A.

STORE AND SALESROOMS

301-303-305 Market Street, San Francisco

LOS ANGELES OFFICE

402 VAN Nuys Building

Experiment Farms, SAnta Rosa, California

Not Open to the Public

Proving Grounds, Sebastopol, California

Not Open to the Public

Nurseries located in

Sonoma County, Solano County, Merced County and

A lameda County, California

Demonstration Station, Broadmoor, Oakland, California

OPEN TO THE PUBLIC

Seed Farms, Santa Clara Valley, California

Spineless Cactus Nurseries, Santa Rosa and Livermore Valley

Warehouse and Distributing Pcint, Oakland, California

Address all Communications to the General Office at

SAN FRANCISCO, CALIFORNIA

Cable Address "Burbank," San Francisco

Western Union Code. A. B. C. Code, 5th Edition 


\section{The Luther Burbank Company}

San Francisco. Cal. U.S.A.

\section{Important Announcement}

On account of the constant addition of new varieties, the nursery and seed stock of The Luther Burbank Company is now the largest and most complete in the West. The reason of this is the unusual facilities for plant propagation, the extensive proving grounds in various sections of the State and a highly specialized organization.

This catalog by no means represents the full list of our nursery productions. It contains, however, a sufficient selection to cover the general needs and should you not find listed the plants that you want, write us and we will supply them to you at once. Everything we offer is new and of the highest standard. Our trade mark seal is a guarantee of quality.

The Luther Burbank Company is the sole distributer of the Burbank Horticultural Productions and this catalog contains original Burbank novelties never before offered mankind. They are but further evidence of the great genius of Luther Burbank, who is now freed from all encroachments upon his time and energies which the attention to the introduction of his productions would entail, permitting him to devote his entire efforts to the creation of new varieties of plant life and improvements upon the old.

Every day brings Luther Burbank new honors and a steadily increasing admiration, not for what he has done, but for the new things he is accomplishing in plant production. His original creations are no longer confined to his own proving grounds or an immediate environment. Through The Luther Burbank Company, the outside world now procures the latest materializations of Burbank's distinguishing genius.

To give each purchaser a guarantee of receiving original Burbank creations, this corporation has originated a trade mark, a facsimile of which will be seen on the front cover of this catalog. The name "Burbank" has been so indiscriminately and fraudulently used that it has been in danger of losing, in a measure, its true significance. Every package of seed and every plant sent out from this corporation will have this trade mark on it. All fraudulent uses of the same will be vigorously prosecuted and any information that will give knowledge of its misuse will be welcome. The trade mark is your protection. It is a guarantee.

The Burbank nursery novelties we offer are early bearers; in fact the great majority of the trees offered you this season are yearlings that have been proved delicious fruit bearers all along the nursery rows. Years and years of experimentation and investigation have been spent in instilling a character of early and perpetual bearing into these trees. The results are certain.

The requests that we have been receiving from growers in all sections of the country are the best evidence of the constantly increasing desire for original Burbank fruits and berries. The reason of this is not based on sentiment. Planting Burbank fruits and berries means assured profits. The consumer wants them-pays for them.

We call your particular attention to the new Burbank Cherry and Plum, both of which are remarkable from every standpoint.

Better fruit, bigger fruit and more fruit per acre is always the goal of Luther Burbank's thought in the development of his new varieties. The results that Burbank obtained are the wonder mark of his success. By taking advantage of what he has accomplished you will attain the reward that comes with successful planting-unusual profits. Remember, Burbank nursery productions are readily translated into money.

Place your orders early, to be sure of obtaining what you desire as the stock of some varieties is extremely limited. Hundreds of orders were unfilled last sason. 


\section{The Luther Burbank Company
San Francisco. Cal. U.S.A.}

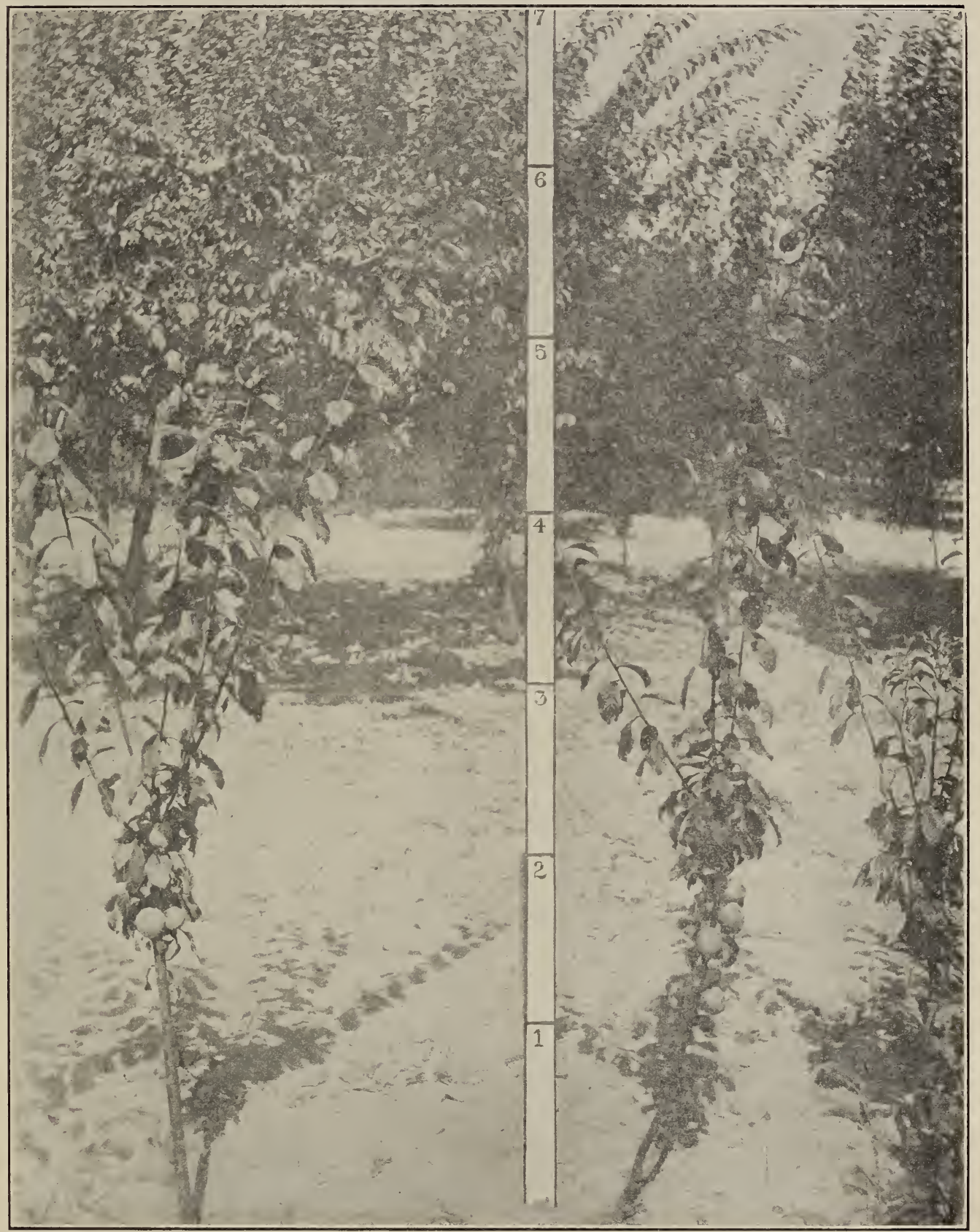

This Shows the Remarkable Early-Bearing Characteristics of the Burbank Fruit Trees. Delicious Fruit Borne the First Season. 


\section{The Luther Burbank Company San Francisco. Cal. U.S.A. \\ The Culture of Trees, Fruits and Berries BY LUTHER BURBANK}

Preparing the Land for An Orchard

Land which is to be used for orchards should be well drained, deeply plowed and thoroughly cultivated as for any garden crop. Extra care in the preparation of the soil will be well repaid in the extra growth and productiveness of the trees. After the land has been thus prepared a base line should be made across one side of the field where the first row is to be placed, and on this line stakes should be driven at the exact places at which the trees are to be planted. The second line of trees should also be marked and staked in the same way and so on over the land on which the orchard is proposed to be planted.

A very good plan for laying out an orchard is to get a piece of wire and have pieces of tin soldered on to it at equal distances along the wire, and by starting at the base line with this wire the distances can be very accurately measured for the stakes.

The usual distance for planting apples is thirty feet; pears and cherries, twenty-five feet; almonds, plums, prunes, peaches and apricots, twenty feet. At thirty feet apart each way, fifty trees will be required per acre; at twenty-five feet apart, seventy trees; and at twenty feet apart, one hundred and ten trees.

Preparation and Planting of Trees

After the land has been staked out, in digging the holes for the trees it will be necessary to have the location of the tree exact, as a crooked row of trees is not a pleasant sight in an orchard. Therefore, before removing the stake for digging the hole it is necessary to have a piece of board about four inches wide and six feet long with a notch in the center and a notch at each end. Fit the center notch to the stake where the tree is to be planted and drive a stake in the notch at each end. Then the hole for the tree can be dug, and in planting the tree place the trunk of the tree in the notch where the stake has been ramoved for digging the hole.

\section{Soils and Location}

The best soil for all fruits is a deep lis ht loam, though fruits are grown we!l on light sandy soils, and some of the fruils, like pears and apples, on quite heavy soils, though peaches, almonds and apricots do not thrive as well on heavy soils.

\section{How to Treat Trees on Arrival}

When trees arrive from the nursery, they should be immediately unpacked and the roots placed in moist soil, which should be well packed around them. In this way they can remain for some time safely until planted. Exposure of the roots to freezing will usually destroy the trees, and in any case drying-out of the roots is injurious. Therefore it is necessary to heel them in this way until ready to plant.

Trees should not be left in the bale as received for any length of time, unless stored in a cool damp place. Trees are sometimes lost by leaving them in the bale after receipt in some windy place, for under these circumstances the roots will become shrunken, and if left too long, the trees will not survive. In case trees are found 
shriveled on receipt, it is well to bury them completely in moist sandy soil for a day or two until they become plump, when they may be planted as usual.

\section{Pruning}

As the roots of trees are necessarily partially removed in transplanting, it is necessary also to remove part of the tops to balance. Trees may best be planted and pruned afterwards. In the case of yearling trees this may be accomplished by simply cutting off the top of all at a uniform height at the time of planting. This is one of the numerous advantages in planting yearling trees. Two-year-old trees may also be first planted before pruning in the same way, but much more wood should be removed. All the branches should be shortened severely, removing half or two-thirds of each branch. Any small and crooked branches should be wholly removed, leaving only three or four leading branches for the head. Also when planting trim off any injured or broken roots with a sharp knife, place the tree in the position it is desired to be and throw in the louse dirt around it, carefully pushing it around the roots, leaving the tree at the same height that it grew in the nursery. Tramp the soil about the roots very hard. If the tree is left loose, the winds will shake it, and if dry, it will soon die out. This tramping is a most important procedure in planting the trees and one which is too often neglected.

\section{Time to Plant}

The best time to plant is usually in the fall, or in warm climates, the early winter, although trees can be planted safely throughout the winter in California. In the colder east it is, of course, necessary to plant either in the fall or the spring. Thrifty yearling trees usually give the best results, but good two-year-old trees are nearly as good and by some are considered better for certain locations.

\section{Berries}

\section{HIMALAYA BERRY}

The distance at which to plant berries depends upon the variety. The Himalaya should be planted in rows eight feet apart and at least six or eight feet apart in the rows, as it is an extremely strong grower, almost like a grape-vine.

\section{PHENOMENAL BERRY}

The Phenomenal and most of the raspberries and blackberries may be planted in rows six feet apart, with the plants four or five feet apart in the rows.

\section{CURRANTS AND GOOSEBERRIES}

Currants and gooseberries are usually planted in rows four to four and a half or five feet apart, according to the variety, and three or four feet apart in the rows.

\section{STRAWBERRIES}

Strawberries for field culture are planted in rows three feet apart and eighteen inches apart in the row for most varieties; some need closer planting, some farther.

\section{PLANTING SEASON}

Many. of the berry plants cannot be planted early in the season, as the tips do not get fully established and well rooted until towards spring.

\section{Fruits}

\section{THE APPLE}

The apple can be more widely grown than perhaps any other fruit, thriving in a great variety of soil and 


\section{The Luther Burbank Company}

San Francisco. Cal. U. S.A.

climate. It thrives especially well and comes to perfection all along near the Pacific Coast and in the foothills and mountains of California, Washington and Oregon, but cannot be profitably grown in the southern part of the State, except in certain localities high up on the mountains.

\section{THE CHERRY}

Cherries thrive best on well drained, warm, deep sandy or alluvial soil, though they will also thrive well on heavy soils, if well drained.

\section{PEACHES AND ALMONDS}

Peaches and almonds also require a loose well drained soil, not thriving as well on the heavy black valley soils of California. This also applies to the nectarine, which is only a smooth skinned peach.

The almond requires a dry climate first and a deep rich alluvial soil.

PLUMS, PLUMCOTS AND PRUNES

Plums, plumcots and prunes thrive best on the deep heavy black valley soils. The Japanese plums and hy- brids will thrive generally on lighter soils than the plums, plumcots and prunes and can be grown much farther south. Some of them thrive well in the southern part of the State, where the common European plums cannot be grown.

\section{QUINCES}

Quinces grow well on either sandy or heavy soil, being less particular in this respect than most trees.

\section{CHESTNUTS}

Chestnuts require a sandy soil, well drained, in all cases.

\section{WALNUTS}

Walnuts thrive on any deep soil, but heavy soils, especially on river bottoms, and valley soils that are strong, suit them far better than sandy soils, where they are often short-lived.

\section{GRAPES}

Grapes require a loose open and well drained soil.

\section{ARTICHOKES AND RHUBARB}

Artichokes and rhubarb thrive on any good farm or garden land.

\section{Changing An Unprofitable Orchard}

For those who have orchards it is generally better to use grafting wood to change unprofitable trees. By this means fruit is produced the second season and samples often the first, and much valuable wood may be produced for next season's nursery or orchard grafting or sale. Many thousand acres of heretofore unprofitable orchards are now producing abundantly of the very choicest and most salable fruits (and shipped East by the carload) from grafting wood of new varieties which were originated by Luther Burbank.

\section{GRAFTING WOOD}

For those who desire to avail themselves of this method we offer a limited amount of grafting wood at the rate of four feet of grafting stock for the price of a single tree of the variety desired. The supply of grafting wood is very limited and only certain varieties can be supplied. Upon application the intending purchaser will be advised if his wants can be met.
It is said by David Starr Jordan, president of Leland Stanford Junior University, California, that: "Luther Burbank is the greatest originator of new and valuable forms of plant life of this or any other age."
"No other man has given to horticulture so many valuable things as has Luther Burbank." -Prof. E. J. Wickson, Dean of the Department of Agriculture of the University of California. 


\section{The Luther Burbank Company \\ San Francisco. Cal. U.S.A.}

EXCLUSIVE BURBANK PRODUCTIONS

The Burbank Apple

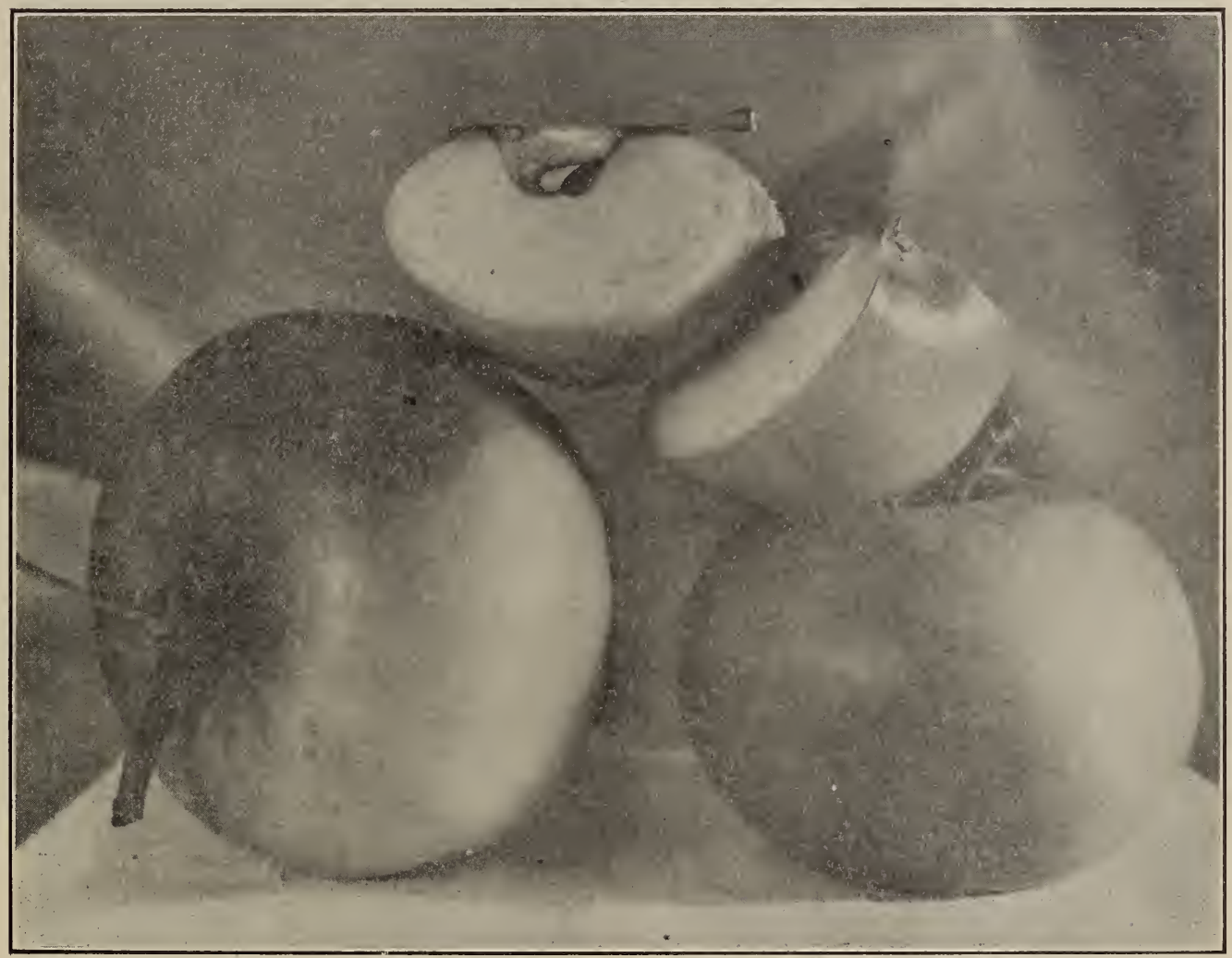

A Delicious New Apple-the "Goldridge"

\section{A New Apple-the "Goldridge"}

Tree a much stronger grower and far better than its parent, the Newtown Pippin.

Fruit large, smooth and as perfect as if turned in a lathe; pale yellow with a crimson blush on sunny side; quality equal to Newtown Pippin with an added aromatic fragrance, ripens earlier along with the Baldwin, Greening and other early Winter apples; unusually handsome fruit. The apple for fruit stand trade or where price is the secondary consideration as compared to perfect fruit. It hasn't any competition.

Price: $\$ 2.50$ each; 10 for $\$ 20.00$.
"I look to great practical results from Burbank's work among plants."-

Thomas A. Edison.
"Mr. Burbank is a man who does things that are of much benefit to mankind, and we should do all in our power to help him."Theodore Roosevelt. 
EXCLUSIVE BURBANK PRODUCTIONS

\section{The Burbank Cherries}

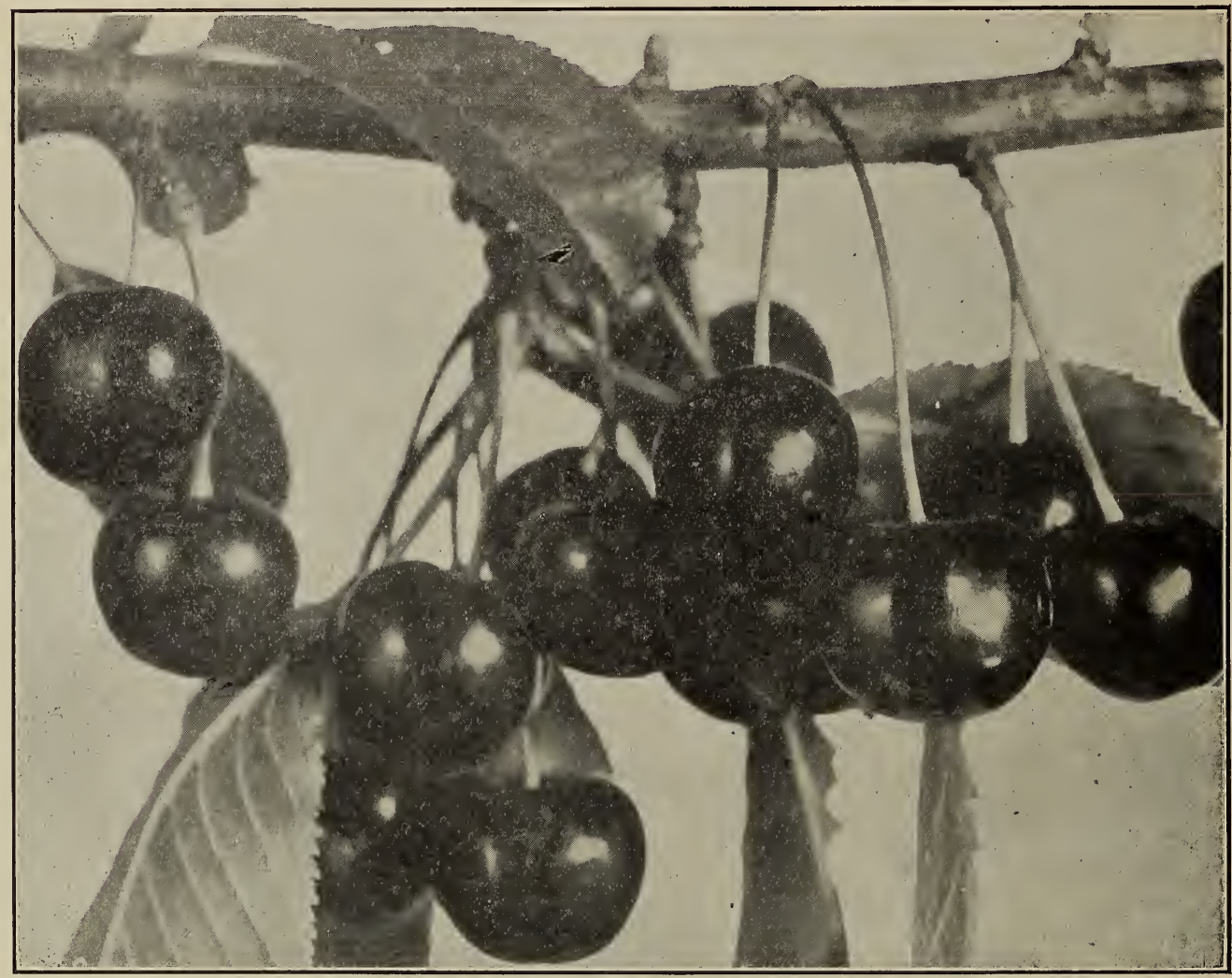

The World's Largest Cherry-the “Giant"-Never Before Offered. (About One-half Size)

A New Cherry-the "Giant"

Never before offered.

The largest cherry in the world. Four cherries weighed one ounce, and eleven well grown fruits measured side by side, twelve inches. Has an extremely small pit with a maximum of flesh.

Mr. Burbank declares: "This enormous cherry outclasses all others in its combination of size, quality and productiveness. The fruit is glossy black, rich, sweet, delicious, being much more productive, a week earlier, larger, handsomer and better than 'Bing,' which has heretofore been classed as the largest black cherry."

Foliage large and heavy, tree rapid, sturdy, well formed grower, with very large wood. Ripens in California about June 20th.

You won't be surprised at the demand for this cherry when you see it. It spells profit to you in its very appearance.

Price: $\$ 5.00$ each; $\$ 40.00$ per ten.

\section{A New Cherry- "Abundance"}

Seedling of Napoleon (Royal Ann).

Tree a strong grower and an early and neverfailing bearer of very heavy crops. Fully twice as productive as its parent-in other words, one-half acre of Abundance trees will produce as many boxes of marketable cherries as an acre of Royal Ann, which heretofore was generally considered as one of the very best canning and preserving cherries.

Fruit larger, handsomer, as firm, better form and color, sweeter and far more delicious, never cracks. Better in all respects. When canned, in appearance and flavor wholly unequaled. The 


\section{The Luther Burbank Company}

\section{EXCLUSIVE BURBANK PRODUCTIONS}

very best, most reliable and most productive late cherry for shipping. Ripens one week later than "Napoleon," just right for the canners.

Remember; it produces twice as many boxes of marketable cherries as the well known "Royal Ann." With the Abundance you can make one acre of cherries yield you the profit of two acres of Royal Anns.

Price: $\$ 1.25$ each; $\$ 10.00$ per ten.

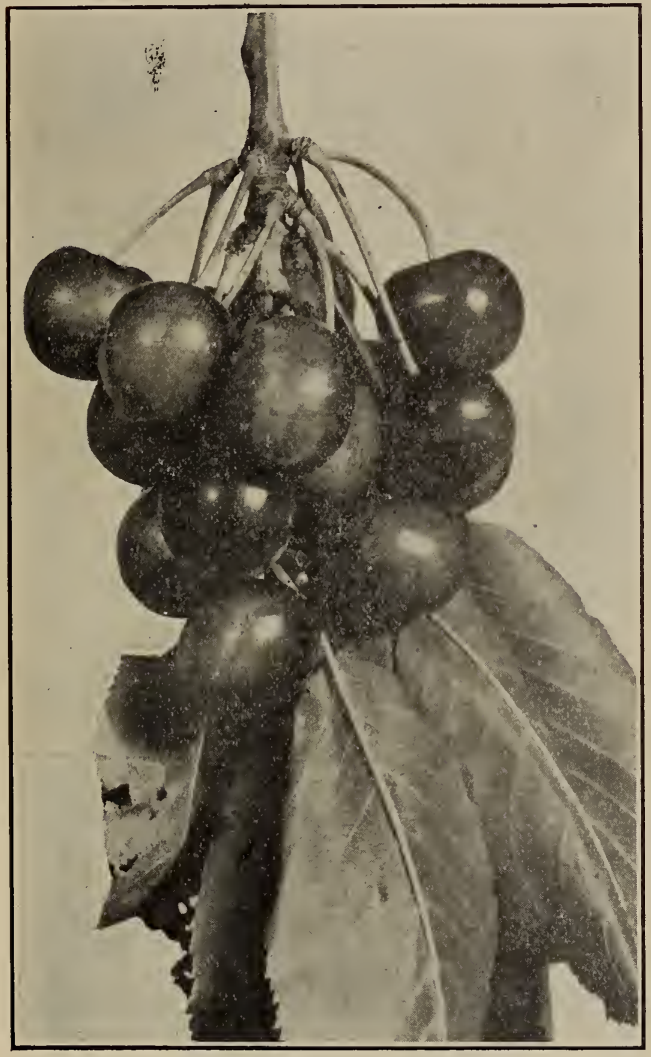

The "Abundance" Cherry-Enormous Bearer

\section{The Early Cherry the "Burbank"}

The earliest of all large cherries. The largest and best of all early cherries.

The "BURBANK" brought in the Eastern States at the wholesale public auction sales in 1908, FIFTEEN DOLLARS PER TEN POUND BOX, and seven dollars and fifty cents per ten pound box later in carload lots, and in 1909 sold again in Philadelphia at the fabulous price of THIRTY-ONE DOLLARS per box of ten pounds. JUST THREE

\section{DOLLARS AND TEN CENTS PER POUND WHOLESALE.}

The TREES are models in form, vigor and never-failing productiveness.

The FOILAGE, which is of unusual size, is so placed that the FRUIT is fully protected from birds and cracking by late Spring rains.

The fruit is extremely large for an early cherry, attractive deep crimson color, and of superior quality.

The "BURBANK" is THE early cherry.

The early market commands the highest prices. The "BURBANK" produces as well or better than most late cherries, but it brings the early market price. This cherry means profit to you.

Price: $\$ 1.00$ each; $\$ 7.50$ per ten.

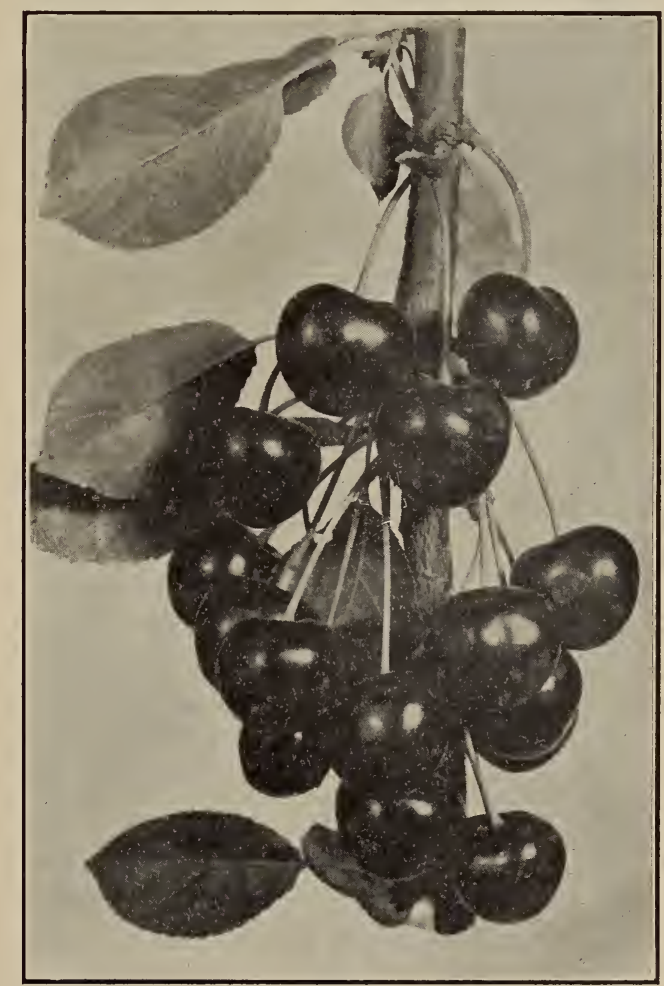

The "Burbank" Cherry-THE EARLY CHERRY 


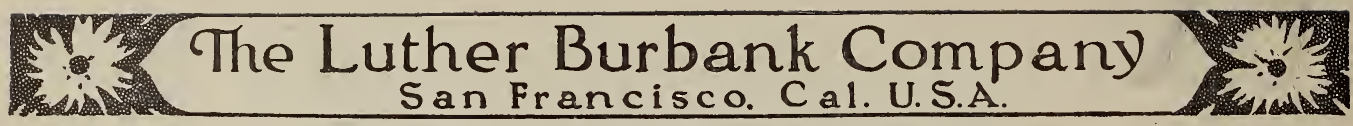

EXCLUSIVE BURBANK PRODUCTIONS

The Burbank Peaches

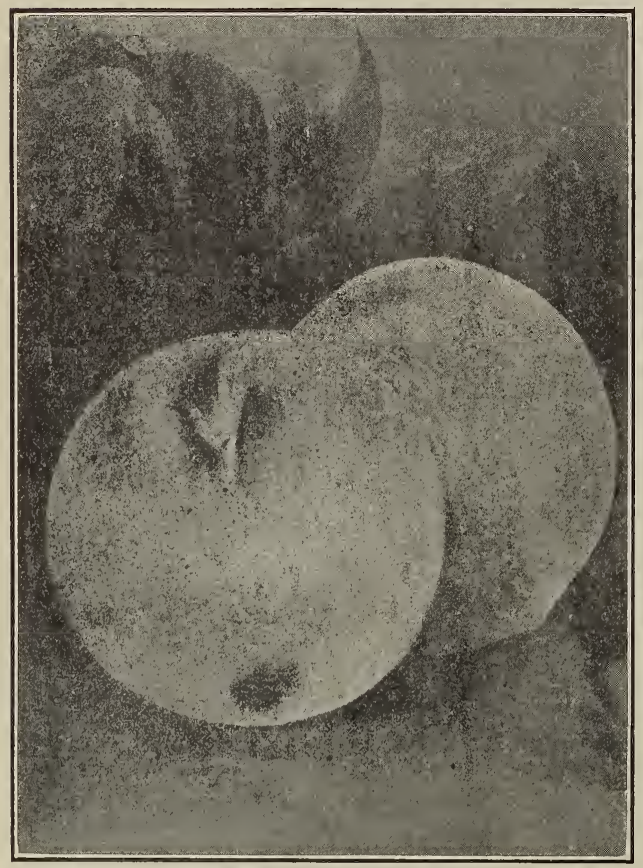

\section{A New Peach-the "Leader"}

The earliest of all the Muir Crawford types, ripening here in July. Unusually vigorous trees, which never fail to produce a full crop of beautiful, smooth globular bright yellow, meaty, firm, very sweet and delicious peaches-far superior to any other. Stone exceedingly small-free. Never a trace of mildew or curl leaf. The very best early peach for canning or shipping owing to its earliness, productiveness, globular form, beautiful appearance, firm delicious flesh and long keeping qualities. A Peach with all the good qualities of the Muir and Early Crawford combined and with the addition of other new ones. As a home peach, it is also unexcelled.

It is the early peach for an early market with the extra large profit to you.

Price: $\$ 1.75$ each; $\$ 15.00$ for ten.
A New Peach-the "National"

A giant Muir Crawford peach which, like the "Leader," is yellow, but is nearly half covered with deep crimson blush and crimson dots. Tree a strong grower and never-failing producer of very firm, nearly globular fruits, excelling either parent. Flesh deepest yellow. Stone small-free. Ripening from ten days to two weeks after the "Leader" and before the old Muirs and Crawfords. Never a trace of mildew or curl leaf. A firm and most delicious peach when canned and for drying or shipping. Extra handsome and extra good also as a market or home peach.

Price: $\$ 1.75$ each; $\$ 15.00$ for ten. $\$$ Opulent Peach

The Opulent Peach is known by growers as the best peach in quality heretofore introduced. Mr. Burbank says:

"Skin creamy white, slightly downy and usually about half covered with crimson dots and blushes. Flesh, light straw color throughout, fine texture, quite firm, yet unusually juicy and with a most exquisite commingling of the Muir peach sweetness and the acid of the White Nectarine, producing what may be called a high vinous flavor. The stone is unusually small and parts perfectly from the flesh."

It thrives over a large part of the United States. Price: $\$ 1.00$ each; $\$ 7.50$ for ten.

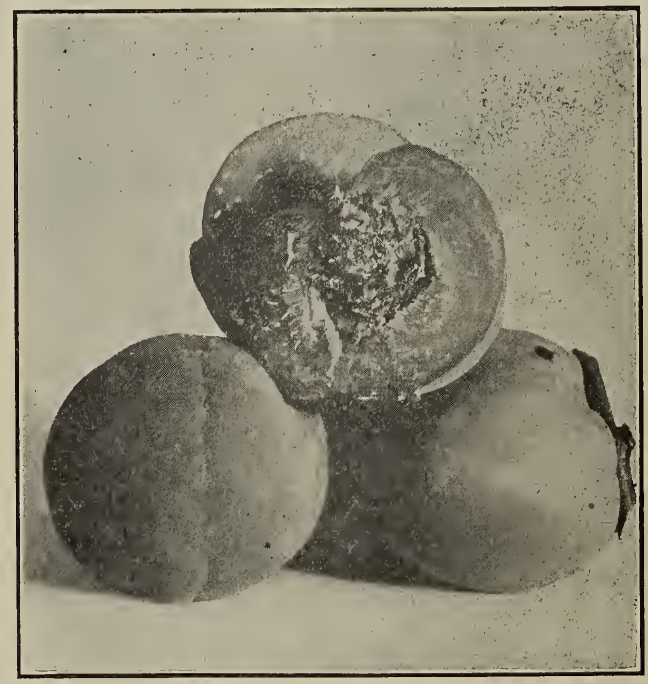

The "National" Peech 


\section{The Luther Burbank Company}

\section{EXCLUSIVE BURBANK PRODUCTIONS The Burbank Plums}

Luther Burbank has accomplished more in the development of new and in the improvement of old varieties of plums than all others combined. Ninety-five per cent of all new plums introduced during the past twenty-three years that have become standard are Burbank productions, although five times as many were introduced from other sources. This record speaks volumes for the genius of Luther Burbank.

These creations here shown include the latest and highest expression of the Burbank skill in plum development. Especial attention is called to the "Gigantic," the world's largest plum, of exquisite quality, the opportunity of obtaining which is here offered for the first time.

For those who desire a continual supply of "quality" plums throughout a long season, it is suggested that an assortment of the following be secured: The "Beauty" ripens June 25th to July 1st; the "Geewhiz," July 25th to August 10th; the "Pasha," August 10th to 20th; the "Glow," September 5th to 20th.

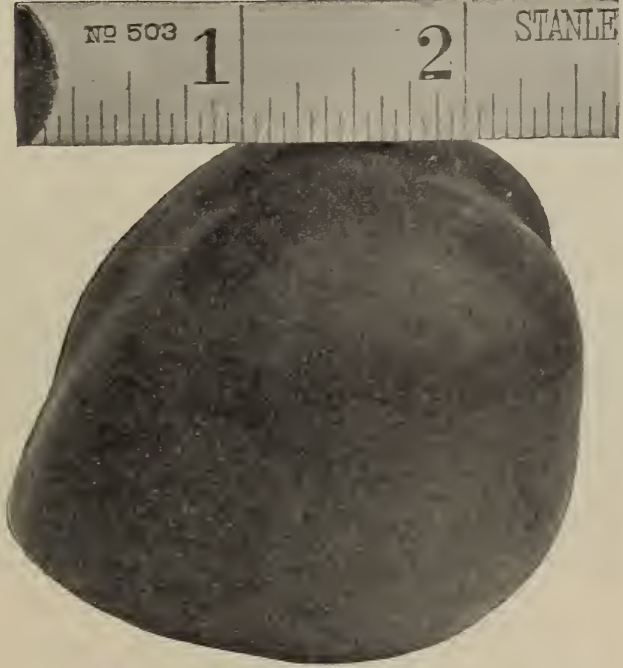

The "Gigantic"-An Average Specimen of the Largest Plum Known

\section{New Plum - the "Gigantic"}

Never before offered. (Provisional name).

This is the most remarkable plum in size ever produced, being the largest plum on earth. It is a good keeper and is green, in color, until ripe, when it turns a clear lemon yellow. Nearly a freestone. The flesh is a lemon yellow and is sweet and fine.

A delightful plum when fresh and of excellent quality when canned or cooked; always canning firm and white.

This phenomenal plum ripens from August 20 th to September 15th and is a fine healthy grower.

This extra large size plum means "extra large profits." Don't overlook it.

Price: $\$ 5.00$ each; $\$ 40$ per ten.

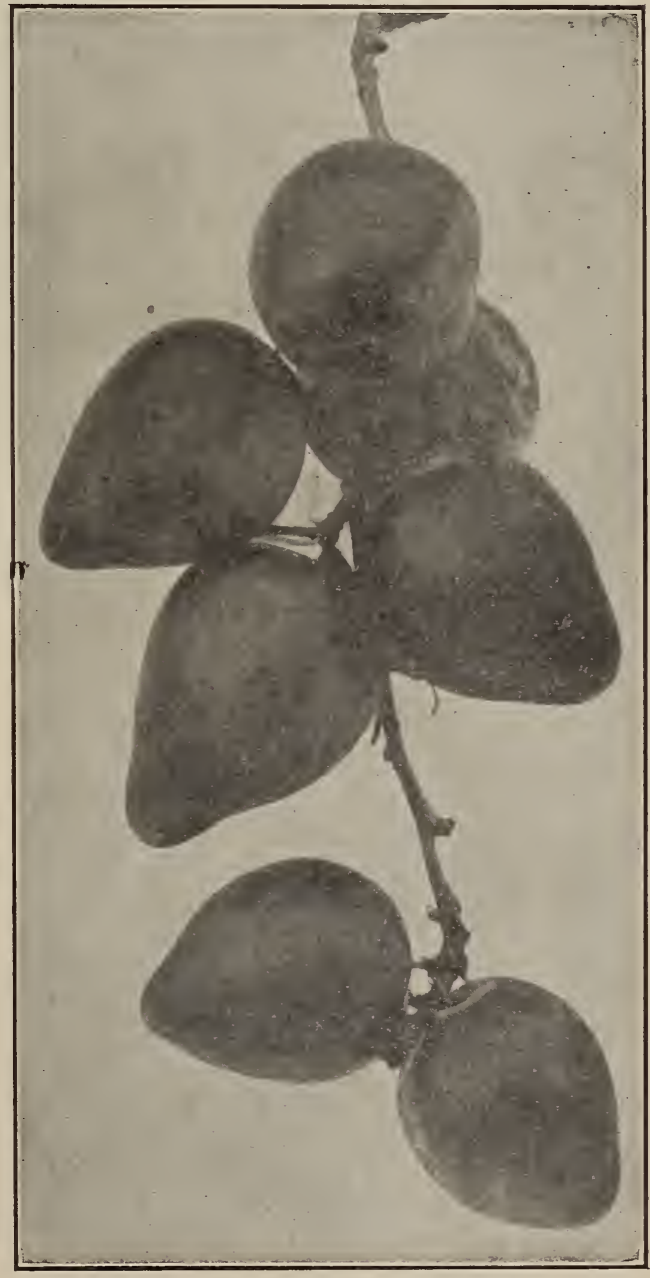

The "Gigantic" is Also a Very Heavy Bearer 


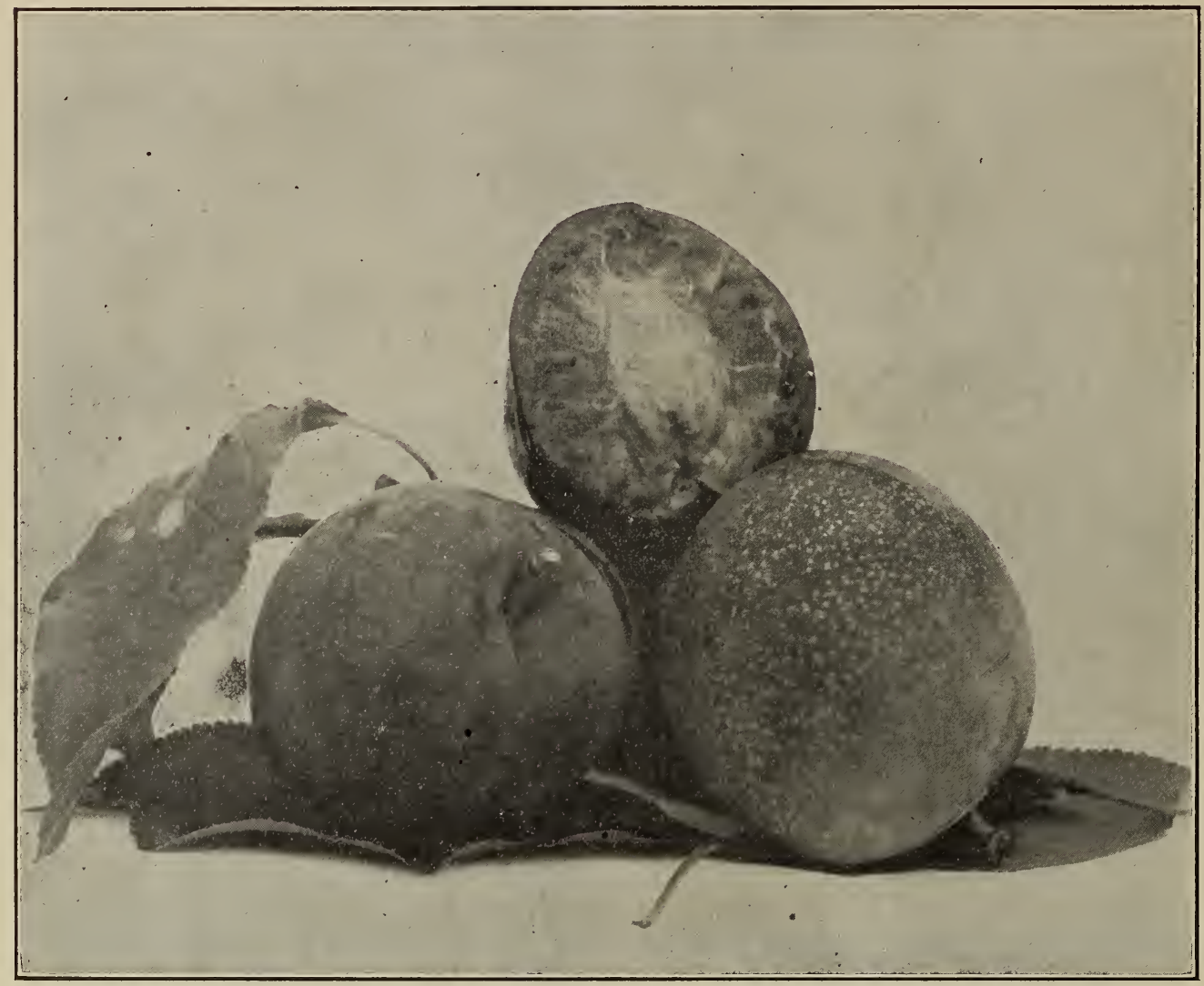

New Hybrid Plum-the "Beauty"-an Early Plum of Exquisite Flavor

\section{New Hybrid Plum - "Beauty"}

It is the product of a very complicated heredity including several species.

Tree a most remarkably vigorous upright grower like the well-known Formosa, with unusually large healthy foilage. Never-failing bearer of full crops of the most beautiful oval crimson fruit two by two and one-quarter inches in diameter. "Beauty," like "Santa Rosa," has flesh light crimson, shaded amber. Is the largest of the early plums and those who know it are preparing to plant it very extensively for shipping to Eastern markets, for while quite juicy, when picked green keeps well, colors up well and develops its delicious flavor. Ripe here June 25 th to July 1 st.

It is a profitable plum because it supplies an early and profitable market.

Price: $\$ 1.25$ each; $\$ 10.00$ for ten.

\section{A New Hybrid Plum L "Choice"}

America seedling.

Tree enormous upright grower and great bearer.

Fruit globular, above two inches in diameter, pure lemon yellow, clingstone. Flesh, golden yellow, firm, rich, subacid, superlatively handsome, extra good keeper and no doubt will be one of the best of plums for shipping as well as one of the hardiest trees known. Ripe, July 25th to August 5th.

Has been fully tested through the past seven years, and will be found to fill the description above to the letter. No hardy plum ever before offered has equal quality, size, beauty, hardiness and productiveness in combination.

It's the plum for Eastern markets. Note the two qualities: Hardiness and keeping or shipping qualities.

Price: $\$ 1.25$ each; $\$ 10.00$ for ten. 


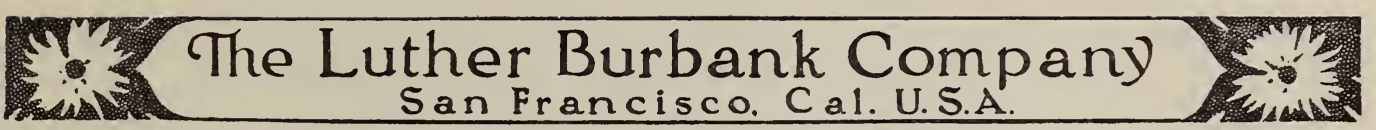

EXCLUSIVE BURBANK PRODUCTIONS

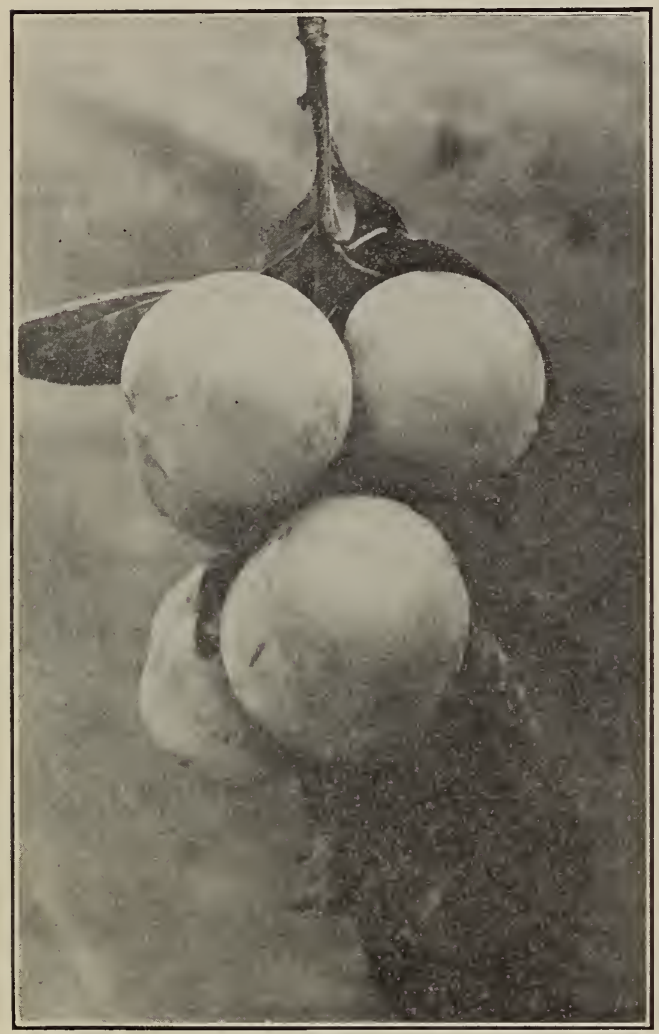

The "Choice" Plum

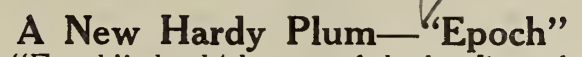

"Epoch" should be one of the hardiest of all known plums, as it is a cross of the Western Sand Cherry (Prunus Bessey) and American plum, both being about as near "Arctic" plums as can be mentioned.

The tree is a compact grower, dwarf, with dark brown wood, which always without fail, produces ropes of fruit, each fruit one and a half inches in diameter, beautiful crimson, with shades and dots of yellow. Flesh pure deep yellow, firm with a rich cranberry flavor, but sweeter, and when ripe very good. Ripens August 15th. The youngest, as well as the oldest, trees literally cover themselves with fruit, which keeps remarkably. Probably the most productive and best of all the "Iron Clad," extremely hardy dwarf plums.

Secure this plum if you want a hardy plum with immense productiveness.

Price: $\$ 1.00$ each; $\$ 7.50$ for ten.

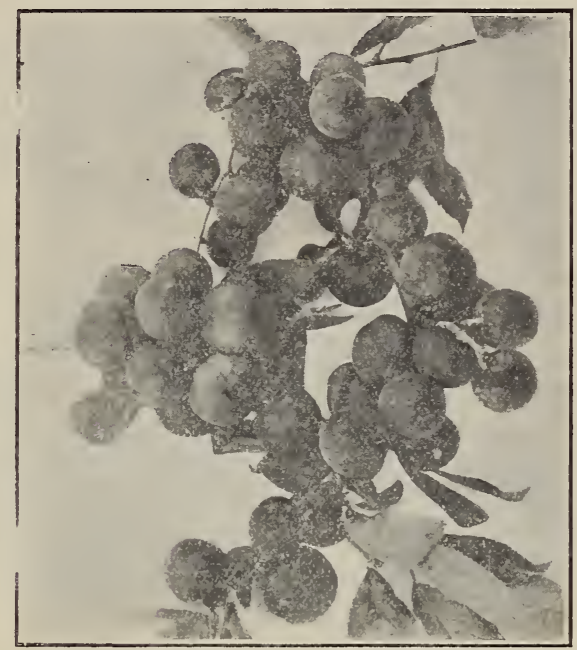

The "Epoch"-Very Hardy

\section{New Hybrid Plum - "Geewhiz"}

One of the most delicious of the many seedlings of the hybrid "America," which, with "Gold," was introduced in 1898. This and "Cold," originated by Mr. Burbank, were the first hybrids ever produced by crossing the American and Japanese species of plums. Both have proved as hardy in the far north as the natives, and being much larger and handsomer, have been widely grown. "Geewhiz," while inheriting all their good qualities, is larger, handsomer and incomparably more delicious. No

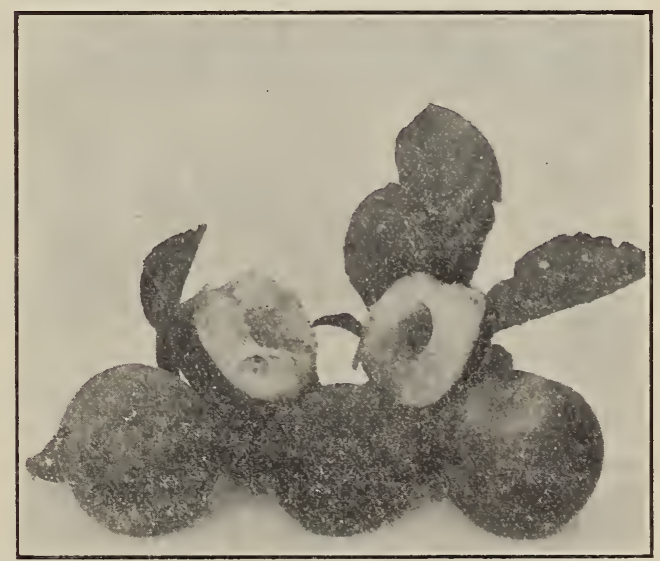

The "Geewhiz"-a Most Delicious Plum 


\section{The Luther Burbank Company San Francisco. Cal. U.S.A.}

\section{EXCLUSIVE BURBANK PRODUCTIONS}

pium now known surpasses it in quality.

Fruit globular, two inches in diameter, crimson blush with numerous crimson dots on yellow gı ound. Flesh firm, pale amber, apricot-like in texture. Exquisitely rich, freestone, good keeper, ripens early - July 25th to August 10th.

Price: $\$ 1.25$ each; $\$ 10.00$ per ten.

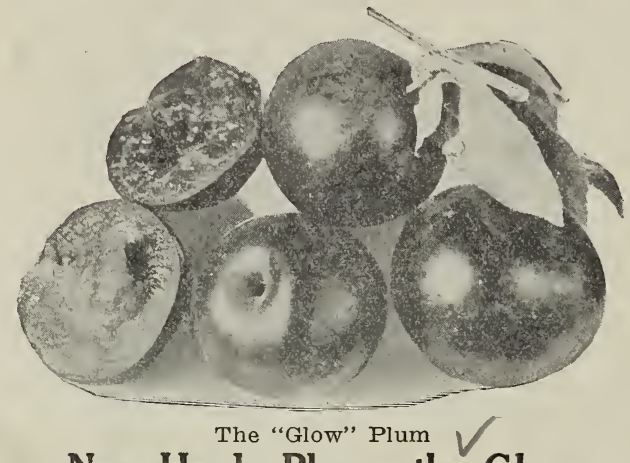

New Hardy Plum - the Glow

This new hardy plum tree is a medium, slender grower with light green healthy foilage and long, slender, drooping branches, which are annually loaded with beautiful fiery crimson nearly globular plums, with faint dottings of yellow. Flesh orange color, rich, delicious (almost incomparably so), partial freestone. Ripens here September 5th to 20th; good keeper, extra fine when canned. Five inches in circumference each way. Price: $\$ 1.00$ each; $\$ 7.50$ for ten.

\section{A New Plum - "Pasha"}

Tree strong grower, tremendously productive. Fruit seven by seven and one-half inches in circumference, oval, light crimson; flesh yellow, rich, juicy and sweet, freestone. Ripens rapidly August 10th to 20th. Remarkable for size and productiveness. Useful for home and near markets.

This very large, handsome plum originated in 1897 and has been well tested for eleven years. Tree a good upright grower and never-failing bearer; firm until fully ripe, when it becomes soft, unfitting it for a shipping plum, but owing to its great size and bearing qualities, will find a welcome place in every home garden.

It is the ideal plum for the home market. This profitable home market is overlooked by growers.

Price: $\$ 1.00$ each; $\$ 7.50$ per ten.

\section{Vesuvius Plum}

Most beautiful of all fruit and foilage trees. Its fruit is of a deep, rich color, possessing a pleasing acid flavor and is produced in large quantities.

Among all known crimson-leaved trees of any kind Vesuvius stands alone. The trees are tremendous growers, taking on a peculiarly picturesque appearance; branches deep purplish crimson, leaves gigantic (often four and one-half inches wide by six long), but above all, these great leaves are of the most beautiful metallic crimson color throughout, both on the upper and under surface, having a crumpled surface very much like a Coleus. Nothing in this line can compare with Vesuvius in color.

Fruit nearly globular, three and one-half inches around, fair quality, especially for cooking, but not an abundant producer of fruit. The growth and foliage of Vesuvius will make it the coming tree for foliage effect, beautiful in the distance, but more so on closer inspection.

No garden or park is complete without some of these beautiful trees.

Price: 75 c each; $\$ 5.00$ for ten.

\section{"Formosa" Plum}

Unusually large, thick, healthy, light green foliage; strong, hard wiry wood; blooms with the Burbank and Abundance and always escapes spring frost, and always bears profusely, even when continuous rainy weather prevents full polination in most other plums. No disease has ever found lodgment with the Formosa. The fruit is of uniform size, averaging about six inches in circumference one way to eight the other. Fruit yellow with a pale bloom until nearly ripe, turning to a clear rich red. Flesh

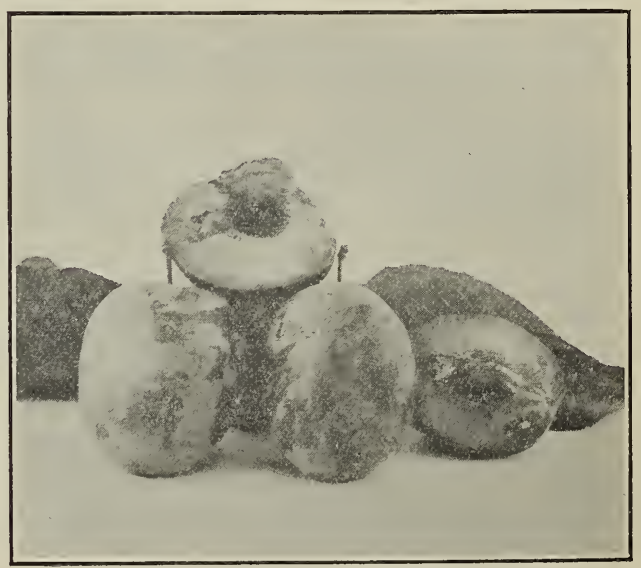

The "Pasha"-a Home Plum 


\section{EXCLUSIVE BURBANK PRODUCTIONS}

pale yellow, unusually firm, sweet, rich, delicious, with a delightful apricot flavor, nearly freestone. Formosa has been thoroughly tested for its keeping qualities, which are unequaled.

This is the plum which commands the extra price; and this extra price means extra profits to you.

Price: 50 c each; $\$ 4.00$ per ten.

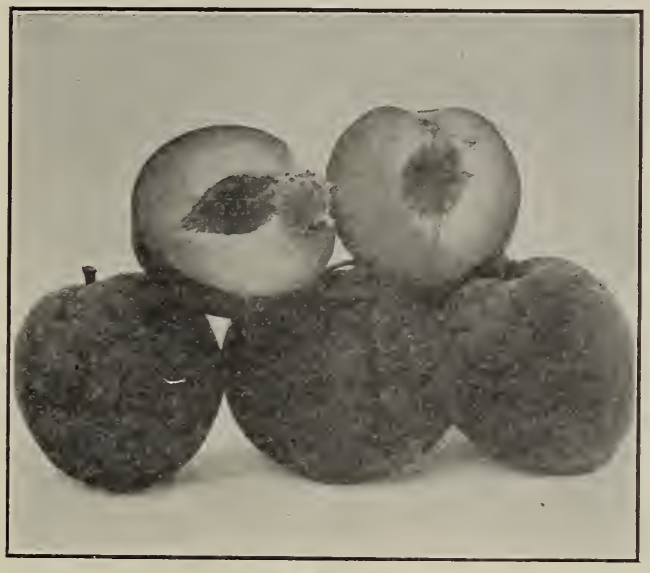

The "Gaviota" Plum

\section{The "Gaviota" Plum}

This beautiful plum is extremely valuable, both as a table and shipping fruit.

Fruit ripens from July 15 th to August 5th, and is of a deep rosy purple color; flesh honey yellow, being very fragrant and sweet to the pit, which is so small that the fruit can be called almost stoneless.

The Gaviota is a late bloomer and always escapes every emergency, and always produces a full crop when nearly all others fail from late frosts or rains during the blooming period.

Price: $50 \mathrm{c}$ each; $\$ 4.00$ per ten.

\section{$\checkmark$ Santa Rosa Plum}

The Santa Rosa Plum received a Gold Medal at the Lewis and Clark Exposition, with special mention for its great size and beauty. Its value as a shipping plum is now very well known.

It is a fine grower, the wood is very tough and the limbs will not break. It is a sure regular bearer and bears always most abundantly. It does not have any off years. The fruit runs remarkably fine, even in size, and astonishingly smooth and clear of any defects. It is beautiful, delicious and a very carrier to Eastern markets. It will keep well in hot weather for a week after it is ripe, so there is no occasion to pick it half ripe in order to ship.

Price: 50 c each; $\$ 4.00$ for ten.

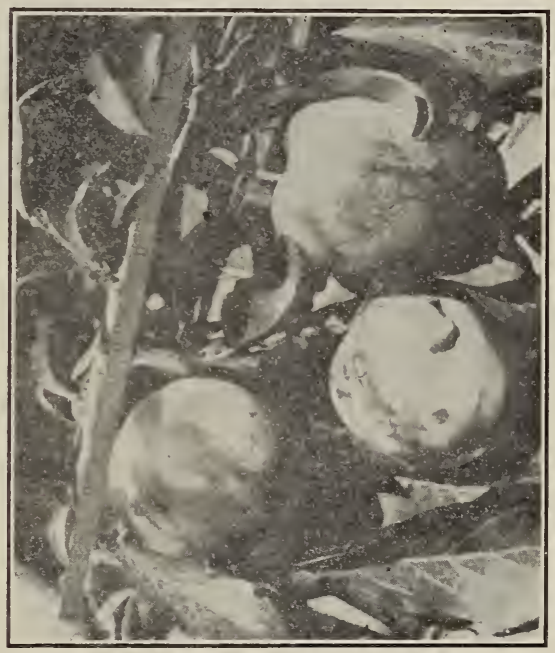

"Santa Rosa" Plum

\section{The Burbank Prunes}

\section{A New Prune-the "Standard"}

"The best Prune ever produced," Luther Burbank.

"The trees are enormous and never-failing bearers, and good, healthy growers. Wellgrown fruits measure four and a half inches around one way by nearly six inches the long way. Skin purple, with a heavy blue bloom; flesh amber or honey yellow, fine grained, juicy, yet firmer than most other drying prunes, very sweet and a perfect freestone.
This is without doubt the best combination drying and shipping prune ever grown; ripens September 1 st and has been kept fully a month in good condition in a basket in an ordinary living-room during our warm Fall weather, and can be shipped when dead ripe with success to any part of the United States and the final test as prune is that when dipped as usual the result is a big quickly dried prune of better quality than any ever before known. No other prune compares with this in its wonderful combination of 


\section{The Luther Burbank Company \\ San Francisco. Cal. U. S.A.}

EXCLUSIVE BURBANK PRODUCTIONS

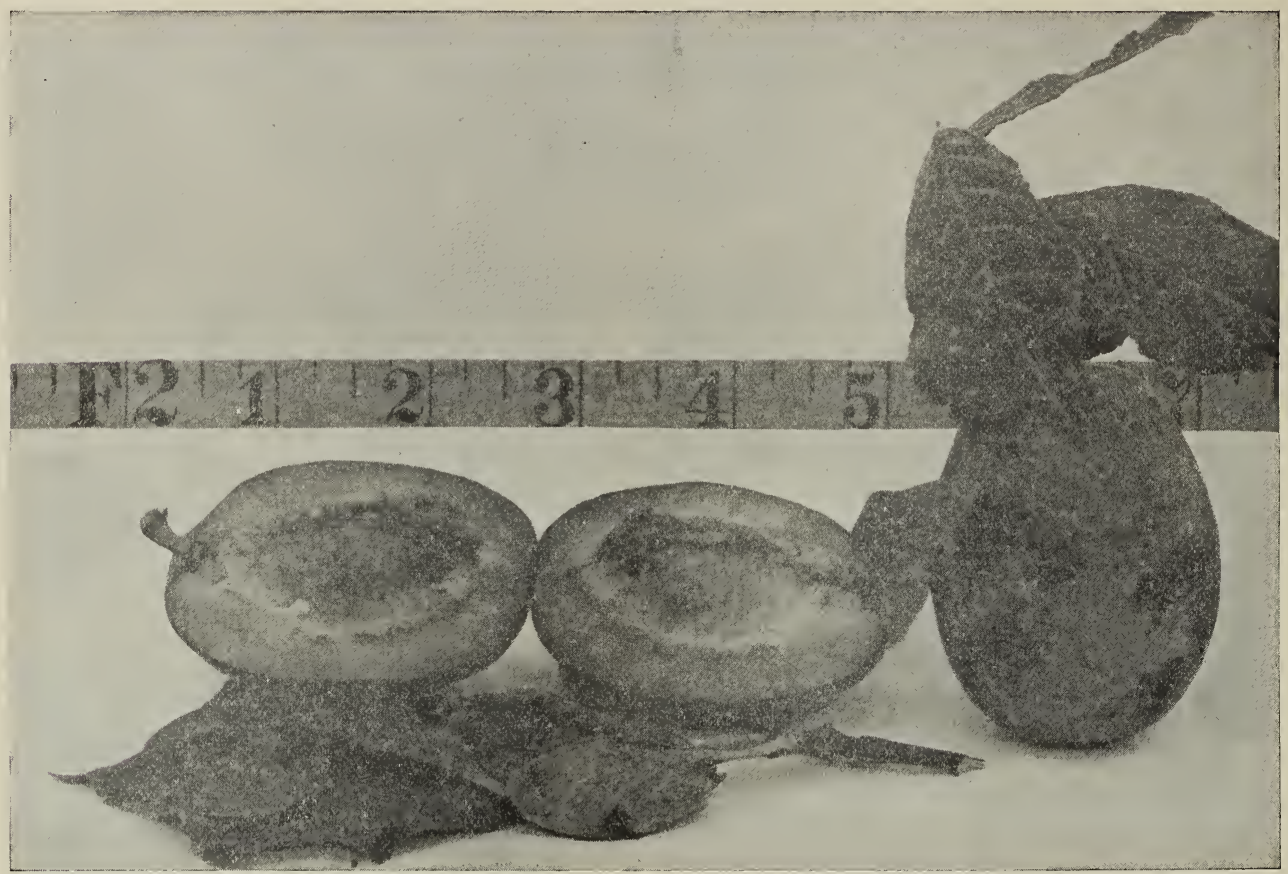

The New "Standard" Prune. "The Best Prune Ever Produced," Luther Burbank

good qualities.

"It has been tried in a commercial way now, for two years, and its possibilities as a highgrade prune have been established beyond question of a doubt." University of California, College of Agriculture. Ag. Experiment Station, Berkeley, Calif.

Examination of Tragedy X Sugar Prune (the "Standard") sample sent by Luther Burbank, Santa Rosa, Calif.

Description by Prof. E. J. Wickson: Freestone, pit small, five-eighths by three-eighths inches. Flesh yellowish, melting, fine grained; very juicy and sweet. Skin dark blue-subcolor dark red, medium texture. Average

Analysis

Average weight in grams.

Number per pound

Flesh, per cent

Pit, per cent

Sugar, per cent

(Signed)

The "Standard" 49.7

9.1

96.5

3.5

18.9

G. E. Colby,

Professor Chemistry.

By analysis it will be noticed that it excels the French Prune in every point. The analysis this season gave a still greater per cent of sugar

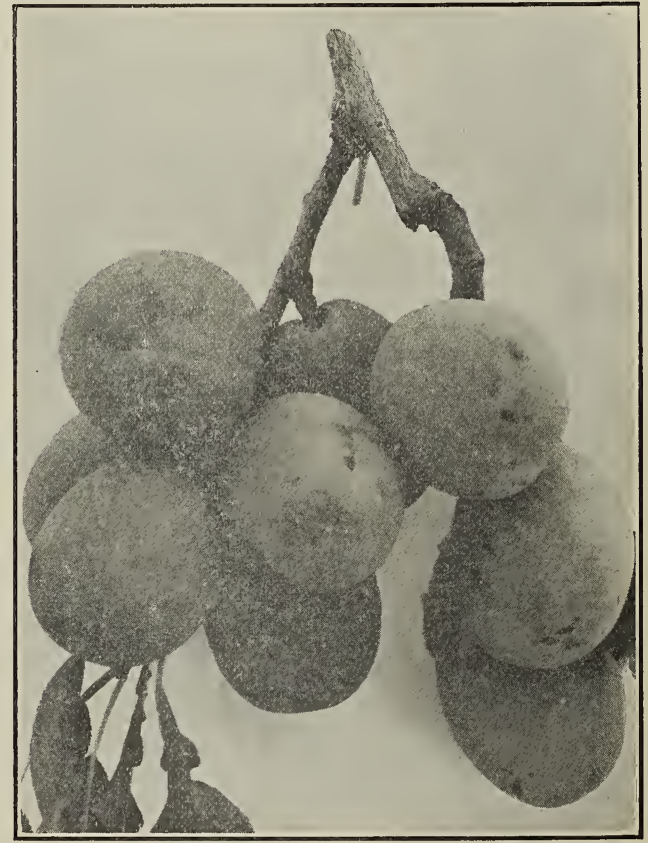

The "Standard" is a Tremendous Bearer 


\section{The Luther Burbank Company \\ San Francisco. Cal. U. S.A.}

\section{EXCLUSIVE BURBANK PRODUCTIONS}

and the fruit averaged even larger.

Better by far than the French Prune. You can't get started too soon growing and shipping this prune.

Price: $\$ 1.75$ each; $\$ 15.00$ for ten; $\$ 100$ for 100 .

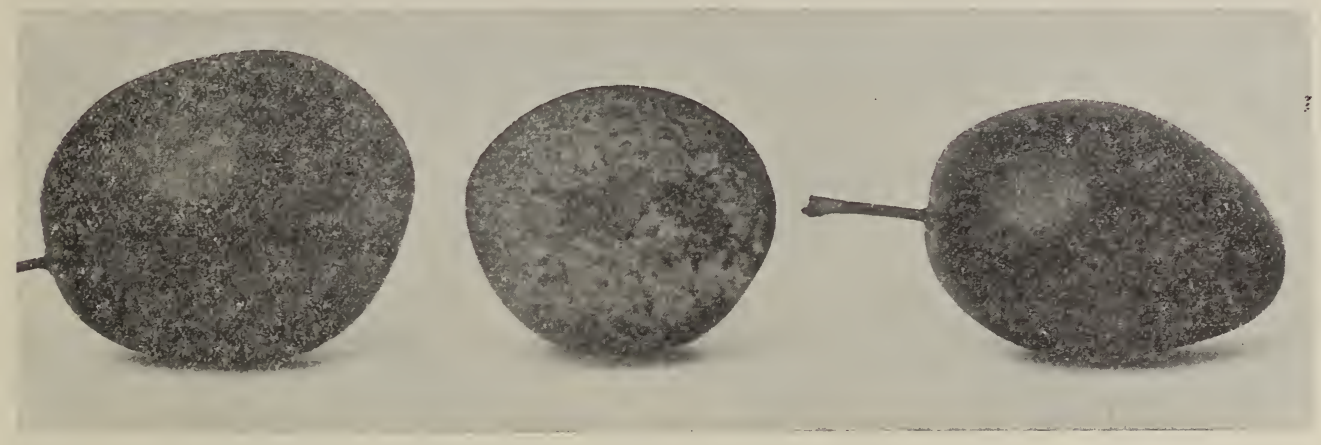

\section{New Stoneless Prune-the "Conquest"}

There has been known for several hundred years a wild plum, an unproductive thorny bush, which bore insignificant acrid, bitter, wild berrylike fruits with only half or two-thirds of a stone. Years ago this was hunted up in Europe with the plan in view of producing really stoneless plums and prunes. The labor and expense incurred in these experiments have been enormous, but among thousands of seedlings, one really good stoneless prune was produced and is here offered.
The tree is vigorous, healthy, rapid grower and unusually productive. The fruit is very similar to its civilized parent, the common French prune, in form, size, color and golden sweet rich flesh. The stone has been eliminated wholly with the exception of a tiny speck. Ripens with the common French prune and is in all respects very much like it in size, quality and appearance.

This stoneless prune is not known to the public and when it is known that there is such a prune the demand will be very large. Grow some of these and be ready for the demand.

Price: $\$ 1.25$ each; $\$ 10.00$ per ten.

\section{THE BURBANK QUINCES}

\section{New Pineapple Quince}

The only Quince in the world that can be eaten raw like an apple.

The flavor is suggestive of the pineapple and can be eaten raw like an apple, the "pucker" taste being absent. Has a most delicious flavor. The Pineapple Quince will cook as tender in five minutes as the best of cooking apples, and with a flavor never before equaled. Jelly made from it is superior to that made from any other known fruit-absolutely unapproachable - something which could never have been thought of until it was brought into existence. The fruit in form and size very much resembles the Orange Quince, but is smoother and more globular; much lighter yellow. Average weight about three-quarters of a pound each.

Price: $\$ 1.25$ each; $\$ 10.00$ per ten.

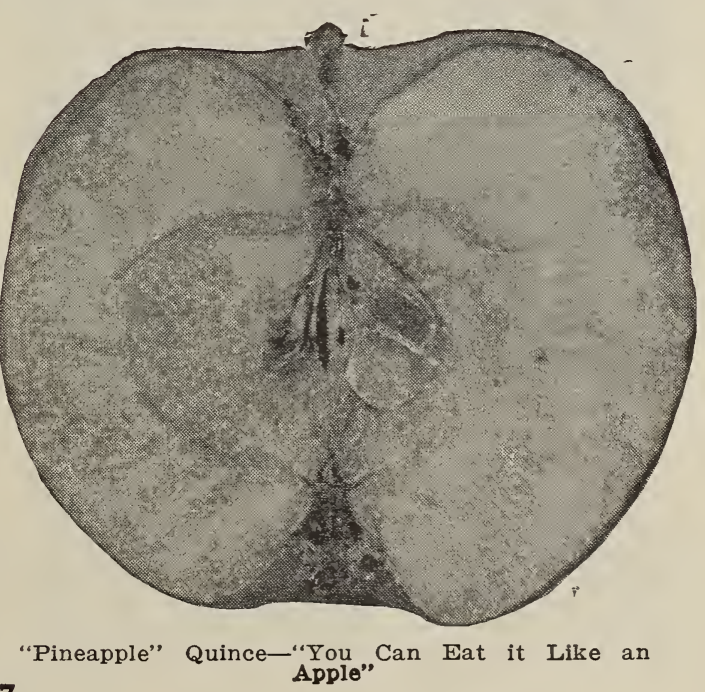




\section{The Luther Burbank Company San Francisco. Cal. U.S.A.}

EXCLUSIVE BURBANK PRODUCTIONS

\section{Quince-_"Van Deman"}

The largest Quince in the world.

This Quince received the Wilder Medal at a meeting of the American Pomological Society at Washington, D. C.

The Portugal Quince has always been considered the best flavored and most tender of all known Quinces, but a shy bearer. THE VAN DEMAN QUINCE, which is a seedling of the Portugal, is not a shy bearer, but will without doubt produce more big, fine-flavored golden fruit than any other.

It is of the most superior flavor, texture and quality for all the purposes for which quinces are used, and in addition is as tender and good as apples when baked, and bakes as quickly, too, and when dried or canned retains all the quince flavor so much admired. This opens a new field, as the demand for these new Quinces when dried or canned will increase rapidly as they become known.

Price: \$1.25 each; \$10.00 per ten.

\section{The Burbank Rapid Growing Walnut}

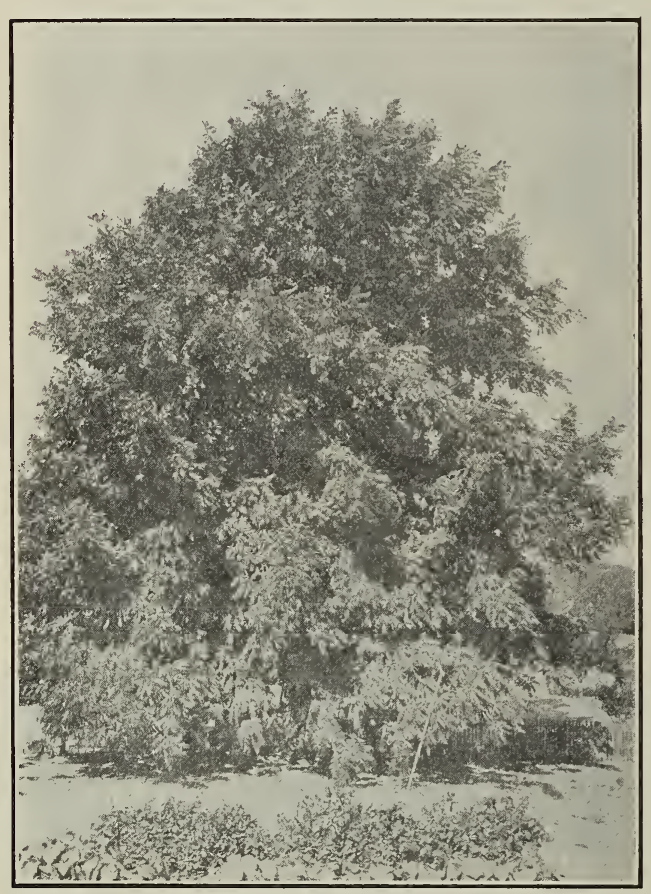

"Royal Hybrid" Walnut-80 Feet High in 16 Years

\section{Royal Hybrid Walnut}

The most rapid growing of the walnuts, growing fully twice as fast as any other walnut. One of the original trees at sixteen years was eighty feet in height, and three feet in diameter breast high. A cross between the native Cali- fornia black walnut and the hardy eastern black walnut, producing large nuts in bewildering profusion at a very early age. While not possessing as high a value commercially as the finer English walnuts, yet the nuts are very much superior to the ordinary black walnuts and must not be confused with them. The tree is especially valuable as a timber tree, and produces a hard, compact timber with a most beautiful silky grain that takes a polish admired by all who see it. The high price of black walnut lumber coupled to the very rapid growth of the "Royal," makes it highly profitable as a timber tree. Is very desirable as a shade or avenue tree. The tree is unusually hardy and is not attacked by borers. It has a most vigorous and hardy root system, and is blight resistant.

These facts, added to its extremely rapid habit of growth render the tree peculiarly valuable as stock upon which to graft English walnuts. There in no equal of the "Royal" Hybrid Walnut root for grafting purposes, and walnuts grafted or budded on it will produce crops when other varieties fail.

It will produce a tree in three or four years sufficiently large for top grafting. By this method a bearing walnut grove will anticipate the ordinary kinds one or more years, and will continue to produce at an increasing ratio larger crops each year than the ordinary varieties.

If you are interested in Walnut Trees you should have some of these Royal Hybrid Walnut Trees. Bridge time by putting them in now.

Extra selected seedlings $\$ 1.00$ each; $\$ 7.50$ for ten; $\$ 40.00$ for 100 . 


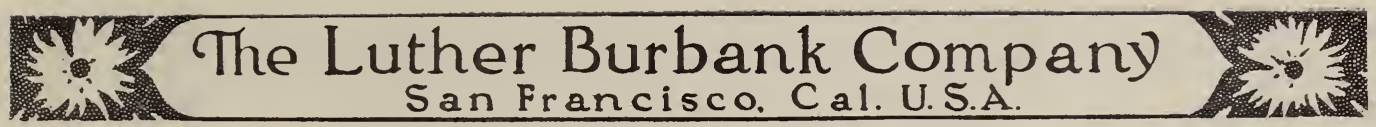

\section{EXCLUSIVE BURBANK PRODUCTIONS The Burbank Plumcots}

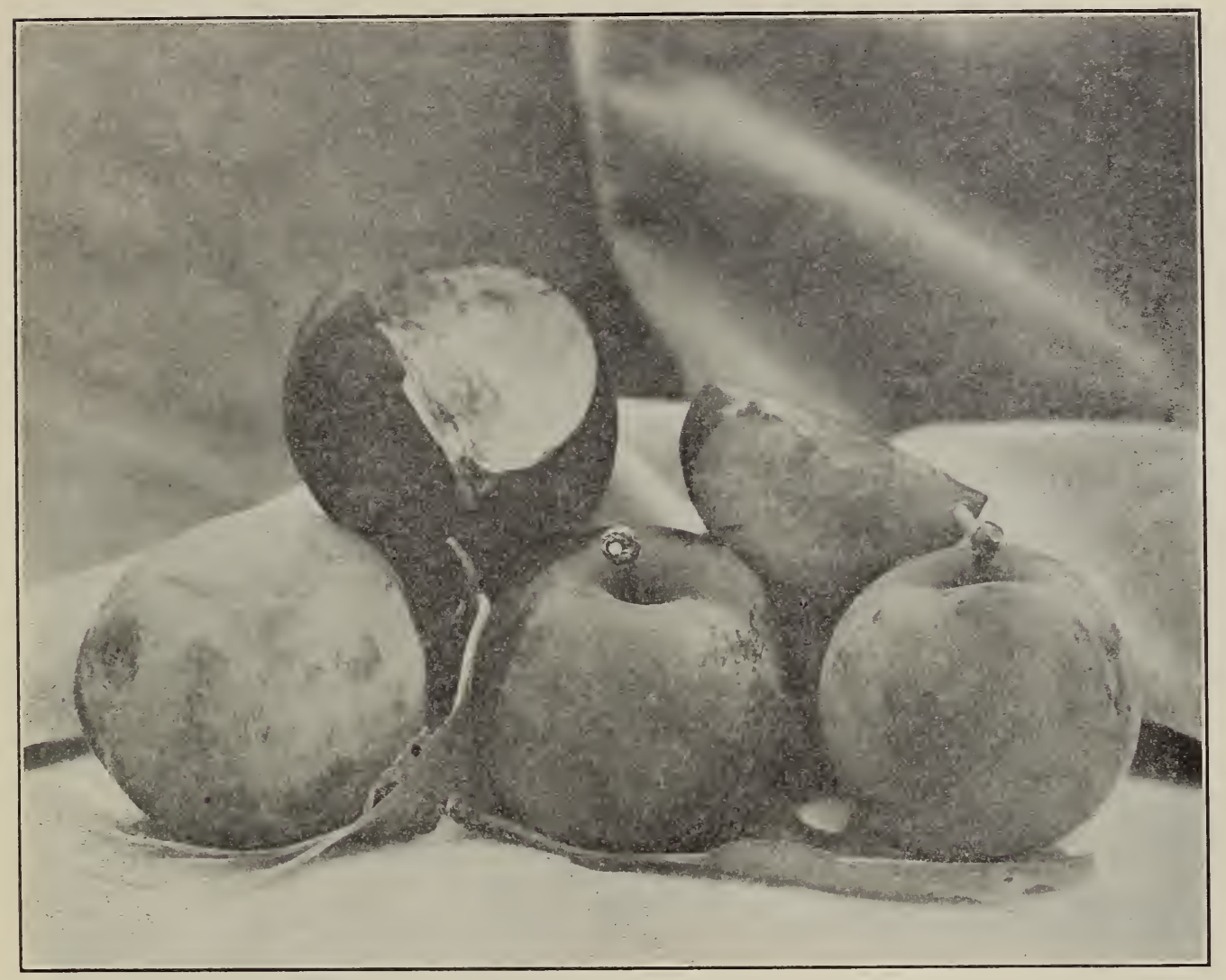

$\checkmark$ The "Apex" Plumcot

A delicious new fruit originated by Luther Burbank.

A happy cross between the plum and apricot. This wonderful new fruit ripens with the very earliest of all the early plums, long before any other good plum or apricot (here June 15 th), which would bring its season about three weeks earlier inland. The tree is a stout, compact, upright grower and has never failed to carry a full crop, even where apricots of all kinds cannot be grown and in seasons when many plums were failures. The fruit is extremely handsome and very large for an early fruit, globular, five and one-half to six inches around each way, beautiful deep pink or light crimson; freestone; flesh honey yellow, firm, rich, aromatic, apricot-like; wholly unequaled in its combination of size, beauty, productiveness and quality by any other early fruit of any kind.
It is novelties like this which pulls your fruit out of the commonplace. Every new variety originated by Luther Burbank has always proven to be very popular.

Price: $\$ 1.25$ each; $\$ 10.00$ per ten.

\section{$\checkmark$ The "Rutland" Plumcot}

As its name indicates, this new fruit is a cross between a plum and an apricot, and it will produce fruits in liberal quantities where apricots fail entirely.

The fruit is about the size of an ordinary apricot with a deep purple velvety skin. One of its striking features is its brilliant flesh possessed of a strong subacid flavor rendering it suitable for cooking, jellies and jams. When fully ripe it is an excellent dessert fruit possessing an apricot-plum flavor.

Price: $\$ 1.00$ each; $\$ 7.50$ for ten. 


\section{The Luther Burbank Company}

EXCLUSIVE BURBANK PRODUCTIONS

The Burbank Berries

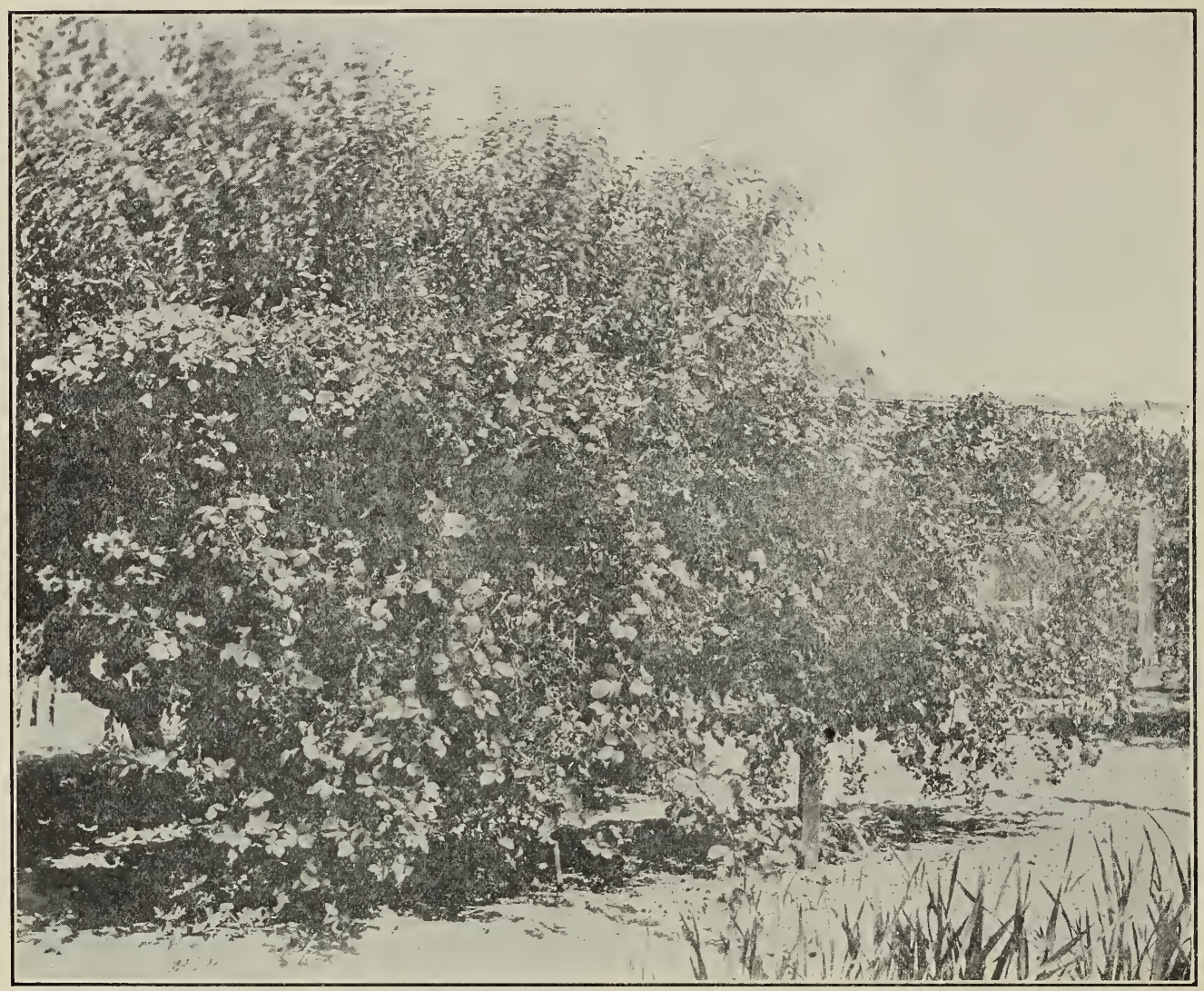

The Original "Himalaya" Berry Vine, Sebastapol Proving Grounds. The Most Productive Berry Known.

The True Burbank Himalaya Berry

The Himalaya Berry is "not like other berries," for it will and does bear more than four times more weight of fruit per plant than any other berry.

Six to eight tons per acre on young fields is a fair crop, but as the plants get older they become almost trees, sometimes producing one or two hundred feet or more of branches each season and berries in proportion.

The Himalaya is a most delicious berry of the blackberry order, unsurpassed in quality, and the best keeper and shipper.

At the Washington U. S. Experiment Station a test was made with all the blackberries grown at the station, the object being to discover what berry would keep the longest in good condition; The Himalayas kept in good condition fourteen days under this test-in other words, fully twice as long as any other berry. So much surprise was caused by this test that it was repeated with exactly the same results. Is it surprising that it is now known as the most profitable shipping berry?

If you want the ideal berry for distant markets this is the berry you should have.

Price: One year old plants, 40c each; $\$ 3.00$ per ten. Tips, $25 \mathrm{c}$ each; $\$ 1.75$ per ten.

Above prices include packing and shipping charges. 


\section{The Luther Burbank Company
San Francisco. Cal.U.S.A.}

EXCLUSIVE BURBANK PRODUCTIONS

\section{The True Burbank Phenomenal Berry}

This berry is one of the most wonderful berries known to mankind, producing a berry larger than any berry ever known, of a bright crimson raspberry color. A cross between the improved California dewberry and the Cuthbert raspberry; an absolutely new berry. Each plant produces annually eight to ten stalks or canes about twelve feet in length. Berries grow in remarkable profusion in clusters of five to ten or more, and individual berries often measure three inches around one way by four the other, and weigh one-fourth ounce. When seen, the question is asked, "Are they sold by the dozen?"

A few plants in the family garden will produce a wonderful supply of berries for home use. A most delicious and popular berry, unexcelled for the table, preserving or drying.

The demand for this berry has never been met Very hardy. Is a splendid shipper, making it ideal for the market. A single acre of young plants has produced over $\$ 1000$ a season.

You'll get the highest price for this berry and get the class of trade which is always looking for the best.

\section{A New Strawberry -"The Patagonia"}

\section{The New Burbank Hybrid Straw- berry-"The Patagonia"}

Mr. Burbank says:

"Of the twenty standard varieties of strawberries now growing on my home places the "Patagonia" commences to ripen first and continues to bear the longest.

Well grown plants are about one foot in height and twelve to eighteen inches across. The leaves are large and unusually thick and firm, with a thin silky down, and are never injured by sunburn, where other varieties are either seriously browned or wholly destroyed.

The berries grow on stiff, branching stalks, which, while generally holding the berries free from the ground, yet do not expose them to the hot sun, so that in warm, dry weather the berries keep here in best condition a week or more on the vines. The berries are uniformly large, single
Price: One year plants, 50c each; $\$ 4.00$ per ten. Tips, 30c each; $\$ 2.00$ per ten.

Above prices include packing and shipping charges.

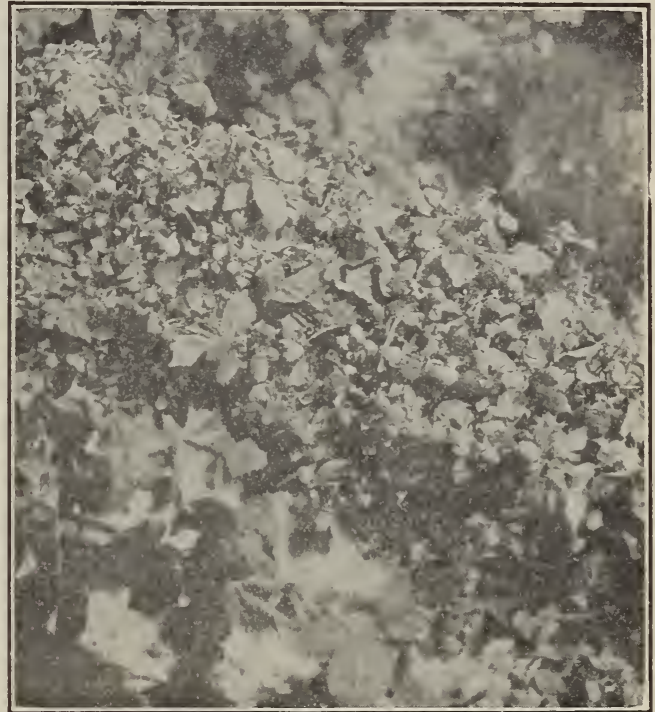

The "Phenomenal", Berry-the Largest Berry Known

berries sometimes weighing an ounce each at the beginning of the season, decreasing somewhat in size during the heat of mid-summer, but are even larger in the fall if the runners have been removed; fine scarlet color with a handsome pale yellow flesh. The seeds are so very small as to be almost imperceptible.

The berry, though firm and a remarkably good keeper, is of most exquisite quality, melting in the mouth with a sweet pineapple, strawberry and dreamlike flavor, and can be freely eaten by those who cannot eat the common acid strawberries now grown.

But above all, this new strawberry is a home berry. Easy to raise, producing great quantities of large, firm, sweet, delicious, pineapple-flavored berries without the usual care necessary to produce good strawberries. It is the first of a new race which has come to make strawberry grow- 


\section{The Luther Burbank Company}

EXCLUSIVE BURBANK PRODUCTIONS

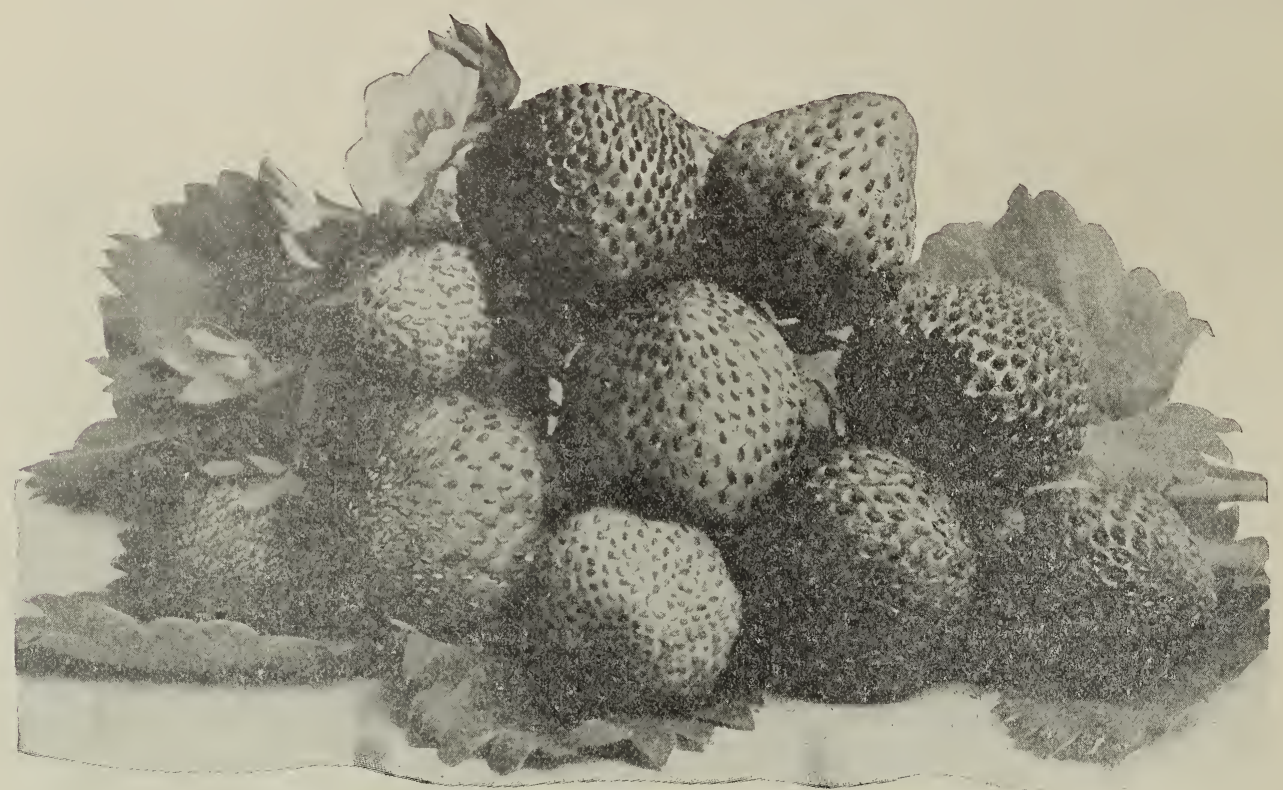

A New and Improved Type of Strawberry, "The Patagonia"

ers rejoice.

This new strawberry is confidently expected to take at once the same high place in the estimation of planters, dealers and consumers that the Burbank potato, Burbank plum, Shasta daisy, Burbank ánd Santa Rosa roses. Giant Winter rhu- barb, Phenomenal and Himalaya berries and our numerous other productions have taken, becoming world-wide standards of excellence-in other words, of the "Burbank Quality."

Price: Plants 25c each; $\$ 2.00$ per dozen.

\section{The Burbank Artichoke}

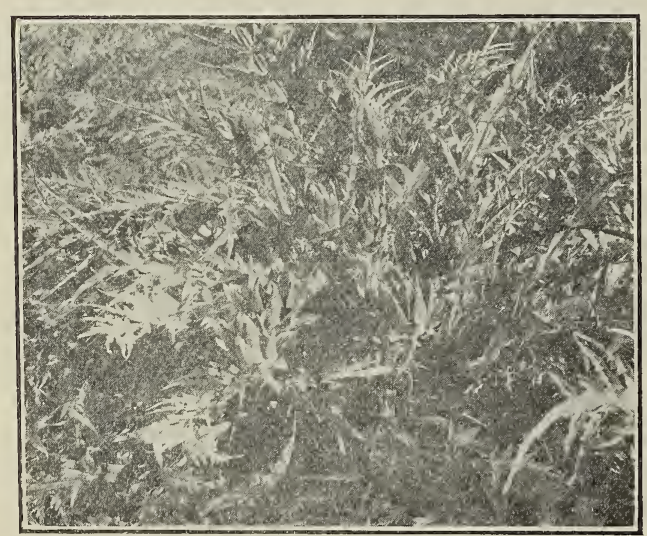

The "Santa Rosa" Artichoke

\section{New Giant Artichoke- "Santa Rosa"}

This new artichoke produces the largest heads known and of exquisite quality, the flowers being sometimes over three feet in circumference. The heart is unusually large and superior in quality to any artichoke heretofore introduced. Remains tender and sweet longer than any other variety. The silvery gray foliage renders the plant highly ornamental, making a pleasing combination of beauty and profit.

You know the demand for artichokes and when you can now supply them in the extra large size you get an extra large profit. Don't overlook this.

Price: $\$ 1.00$ each; $\$ 7.50$ per ten. 


\section{The Luther Burbank Company
San Francisco. Cal.U.S.A. Th EXCLUSIVE BURBANK PRODUCTIONS The Burbank Spineless Cactus}

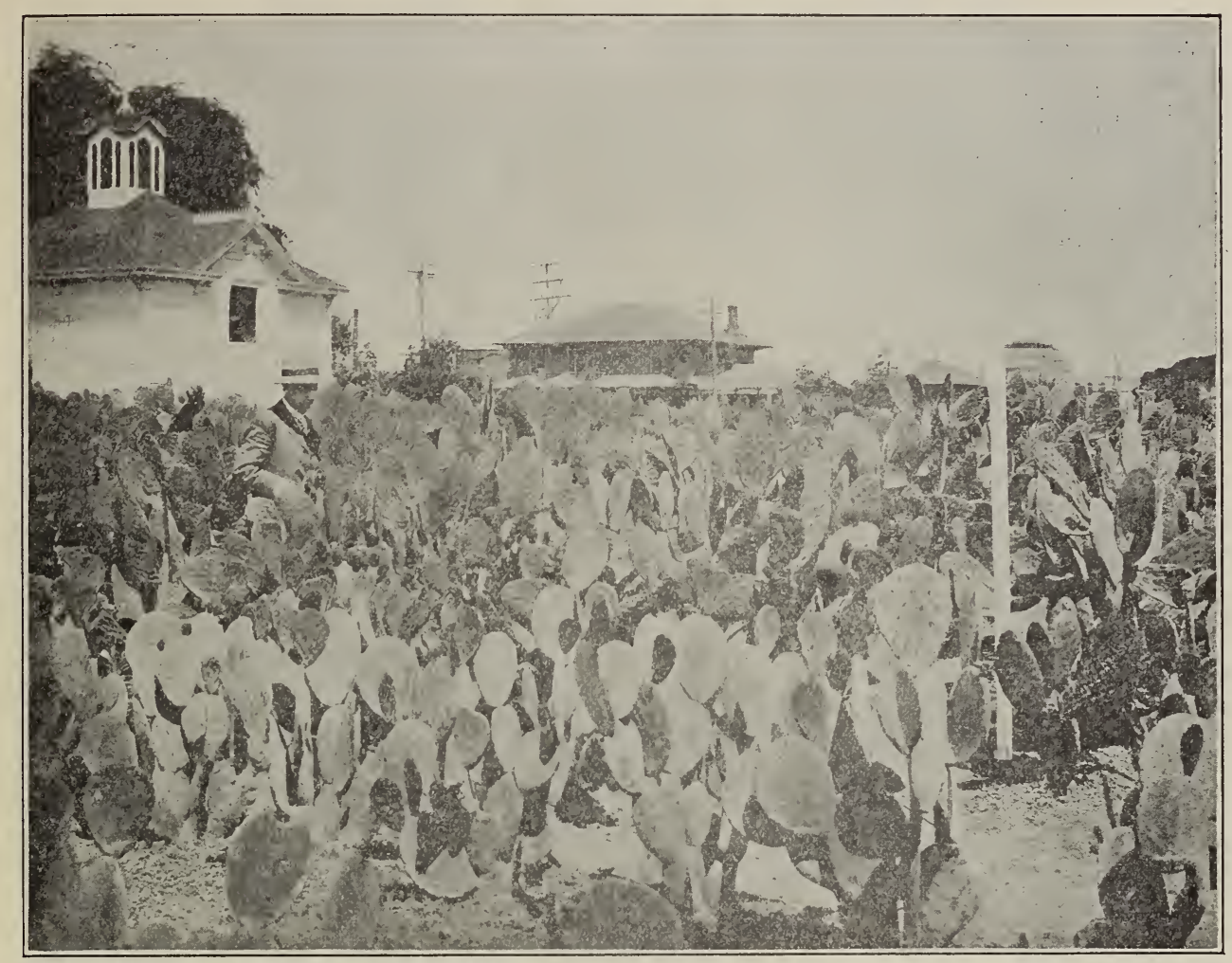

Luther Burbank Standing in the Midst of a Field of Burbank Spineless Cactus, the World's

Burbank Spineless Cactus Direct From the Originator

One acre planted to Burbank's Spineless Cactus will, without irrigation, feed four cows per annum, while one acre of alfalfa will feed but one cow,- - now you will begin to realize the importance of Luther Burbank's Spineless Cactus to you. Besides, Luther Burbank's Spineless Cactus grows where any forage will grow; it needs but four to five inches of rain per season and the precipitation need not be regular. Milch cows fed on Burbank's Spineless Cactus ration gave 47 pounds of milk daily as against 37 pounds daily on an alfalfa ration. Under a recent test held by the Santa Rosa Chamber of Commerce-Hogs fed on the Gienuine Burbank Spineless Cactus made a net gain per hog of $2 / 3$ pound per day. These hogs were fed on Cactus for 22 days. Burbank's Spineless Cactus will produce 100 tons of good forage per acre per annum without irrigation.
If you are desirous of planting this wonderful fruit and forage cactus now or later, place your order immediately and the cactus will be reserved and delivered at any time within six months. You know that the demand for Genuine Burbank Cactus this coming season will far exceed the supply and we urge you to book your order at once. Cactus will not thrive where the temperature goes below fifteen degrees above zero for any considerable period.

\section{FOR FORAGE}

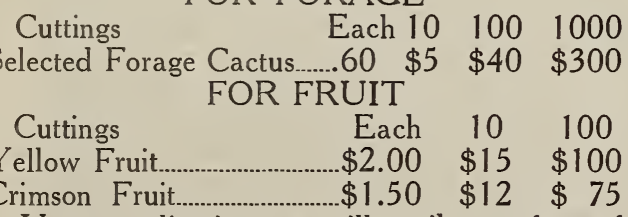

Upon application we will mail you free of charge our Burbank Spineless Cactus Book, which will give you a complete history of Spineless Cactus, written by Luther Burbank. 


\section{The Luther Burbank Company
San Francisco.Cal.U.S.A.}

\section{EXCLUSIVE BURBANK PRODUCTIONS \\ The Burbank Winter Rhubarb}

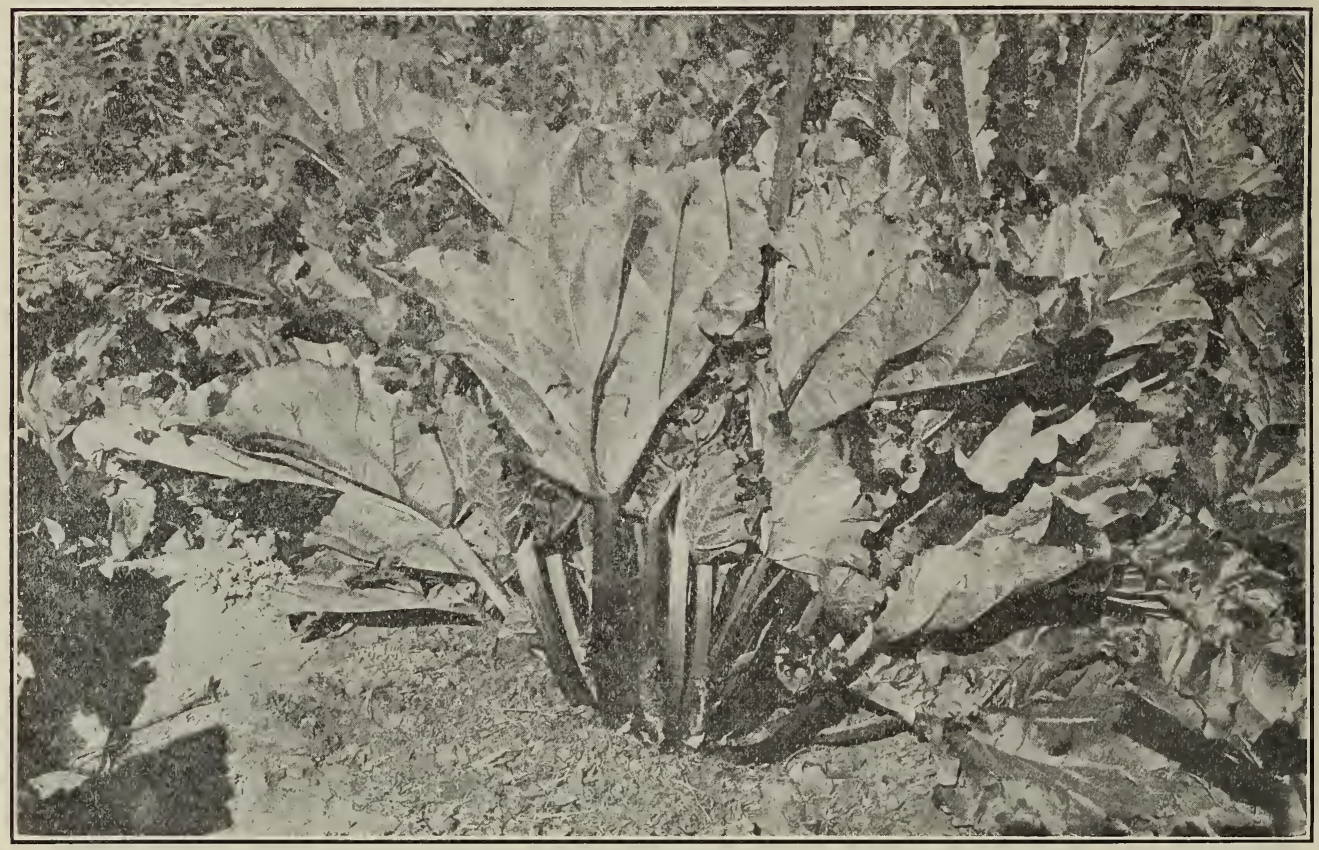

"The Rhubarb Six Months Ahead." Photo Taken October, 1913

\section{Burbank Giant Crimson Winter Rhubarb}

"The Most Valuable Vegetable Production of the Century."

The great value of Rhubarb as a vegetable has always been its earliness, and a vast amount of time and labor has been spent during the last two centuries in efforts to originate a variely which would produce stalks even a day or two in advance of other early varieties. The new "Giant Crimson Winter" Rhubarb will produce marketable stalks abundantly fully six months earlier than any other Rhubarb.

The quality of this wonderful New Rhubarb is far superior to any of the older kinds, having the pleasant taste of berries instead of the coarse ground taste, and tough, green stringy stalks of the old kinds, yet are as large as can be conveniently handled and shipped, producing beautifully colored crimson stalks under good culture two or three feet long and one to one and onehalf inches thick, and producing fully double as much per acre as the old coarse kinds. The main crop comes during the holidays, just at the time when all other Rhubarbs are out of business.

This Giant New Rhubarb is absolutely unequaled in quality, and must not be confounded with the Crimson Winter Rhubarb, as it is much more productive.

This new Rhubarb will not be profitable out of doors where the Eucalyptus, the Orange and the Fig cannot be grown.

A plantation can be secured in a short time from a small number of small roots as this new variety increases about ten times as fast as the best of the old ones. Plant three by six or eight feet apart on any good, well drained land which will produce corn, potatoes or hay.

This Rhubarb can be grown between orchard trees, and in addition to increasing your acre output, it comes at the season when other crops are out and keeps the income steady.

Price: 40 c each; $\$ 3.00$ per ten; $\$ 25.00$ per hundred; $\$ 175.00$ per thousand. 


\section{The Luther Burbank Company}

\section{EXCLUSIVE BURBANK PRODUCTIONS The Burbank Roses}

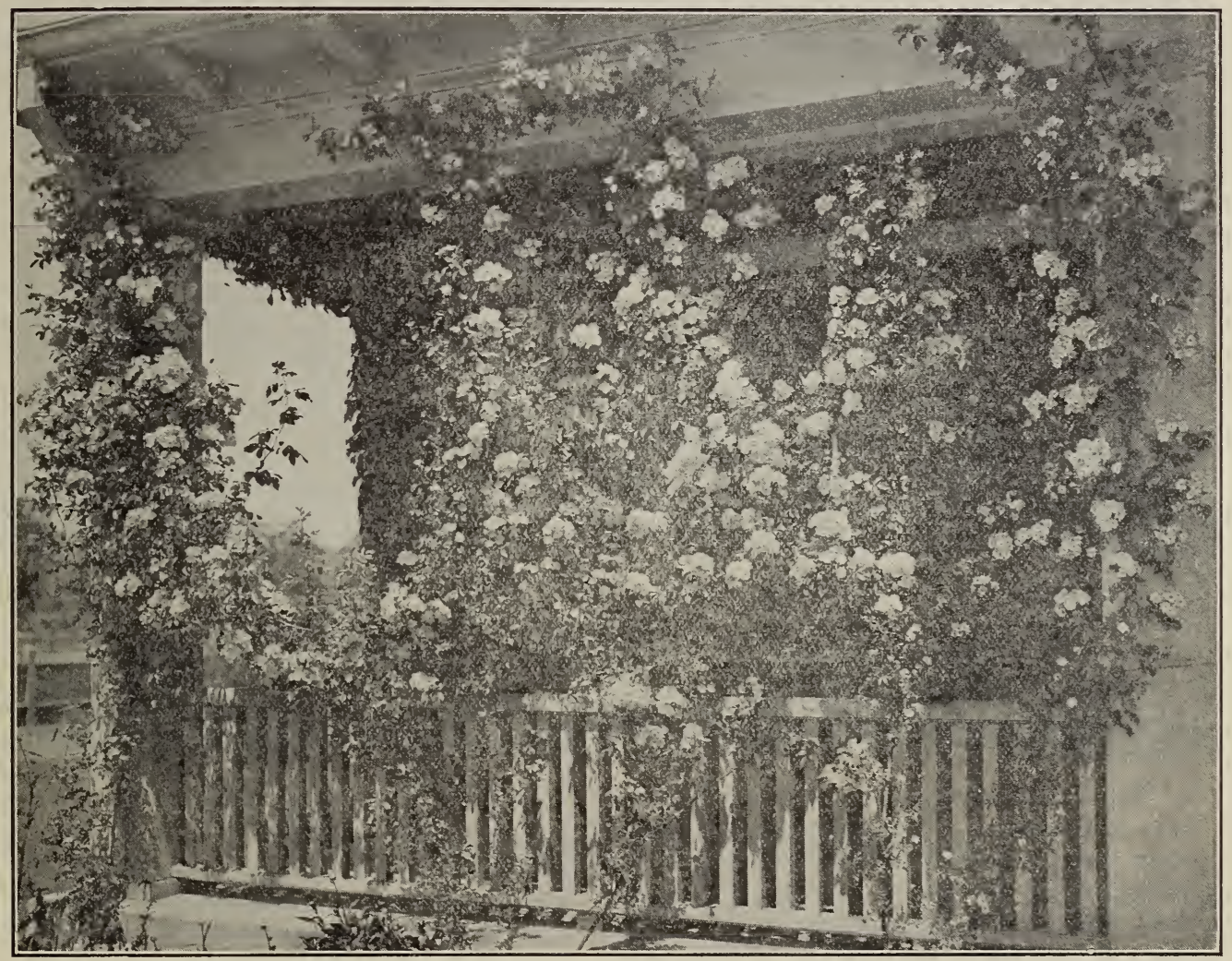

Luther Burbank's New Rose "Corona" on the Porch of Burbank's Home

Luther Burbank's 1914 Rose Novelty- "Corona"

This wonderful new rose is a semi-climber of the Crimson Rambler type, with magnificent single blooms growing in immense clusters. The flowers are rosy crimson, very much resembling Chinese primroses, yet are unlike any rose known.

This, the most unique of all rose creations, has a bloom, which when cut will last in perfect condition for two weeks. This rose is so highly prized by Mr. Burbank himself that it graces his own home veranda, where it has occasioned more comment than any rose creation the past decade.

A bed of these roses growing upon a trellis or against a dwelling is a sight of rare beauty, and as unusual as it is beautiful. The plants are hardy and will grow with but little attention.

You will be more than pleased if you put this wonderful rose in your garden.

Price: Two year Bushes, $\$ 1.50$ each $\$ 12.50$ per ten. One year Bushes, $\$ 1.25$ each; $\$ 10.00$ per ten.

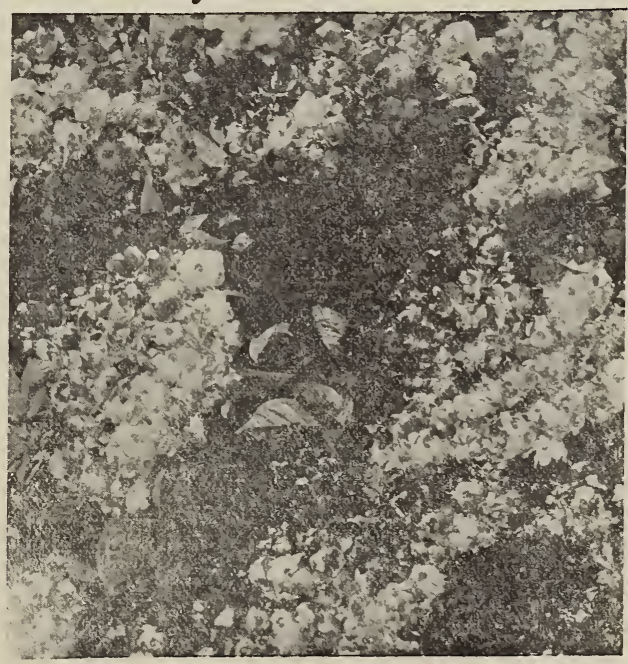

The "Corona" in Detail 


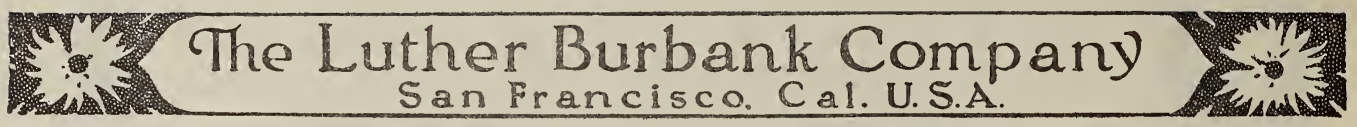

\section{EXCLUSIVE BURBANK PRODUCTIONS}

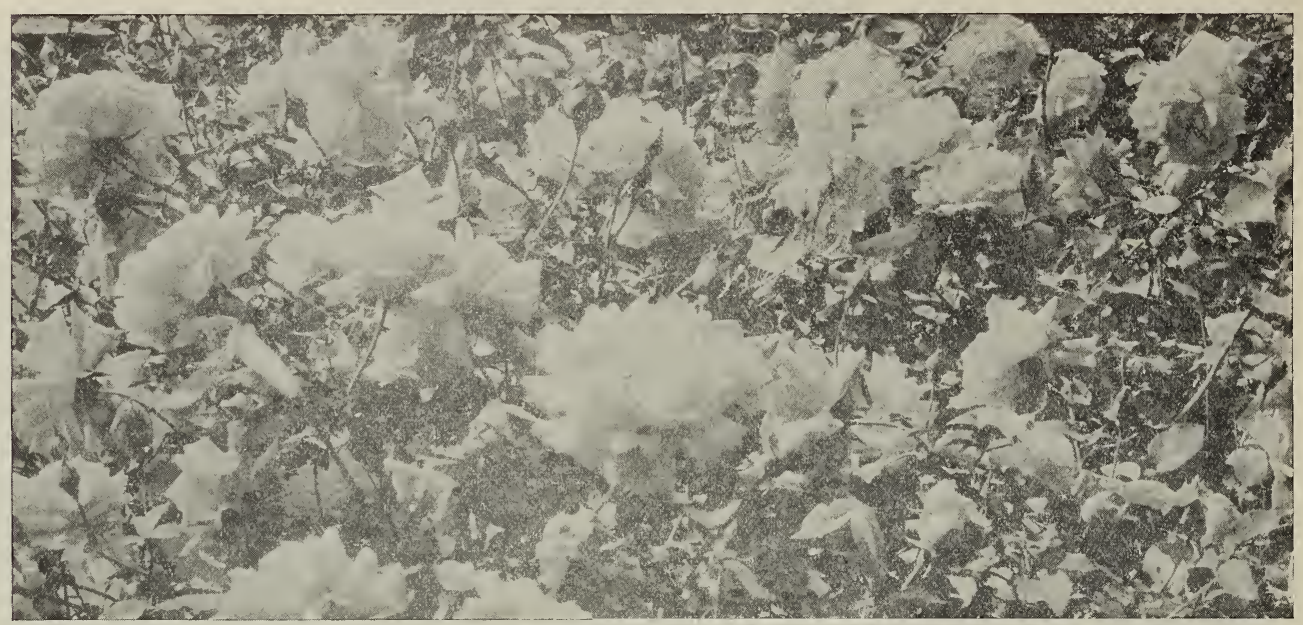

The Everblooming "Santa Rosa" Rose

\section{"Burbank Rose"}

This rose received the gold medal at the St. Louis Exposition as the best bedding rose in existence.

This is without exception the freest flowering rose in cultivation. The plants begin to bloom when only a few inches high, and flower most profusely all through the spring and summer until stopped by heavy frost late in the autumn. The flowers are double, of fine form, nearly three inches across. The color is a deep rose pink, shading to a beautiful soft rose at the center. The petals are well incurved, so that the center is hidden. In September and October the outer petals change to a deep, rich carmine. The Burbank is perfectly hardy and will stand our most severe weather. This is a great point in its favor. It is strong and vigorous, with neat, rich green foliage, not liable to mould or spot. The plant is of symmetrical form, and does not make sparse open growth out of doors, as do so many other choice varieties. Each plant becomes a well-rounded bush that is most effective when grown at some little distance from other plants.

Price: $\$ 1.00$ each; $\$ 7.50$ per ten.

\section{Rose "Santa Rosa"}

(Hybrid Bourbon TEA.)

The old favorite, ever-blooming rose Hermosa, introduced in 1840 , is probably the best known and most widely grown of the entire Rose family. It very rarely produces seed, so that improved Hermosas have not made their appearance until Santa Rosa, now offered, which was grown from second general Hermosa seed with an unusually fine semi-double, thick-petaled seedling of the well-known Bon Silene for the other parent.

In Santa Rosa we have a rose wonderfully improved in size, brilliancy of color and perfection of form, with Hermosa's reckless habit of blooming at all seasons. Every little plant commences to bloom as soon as it starts from a cutting, and the branches, roots and even single buds take root and grow almost as freely as grass.

Flowers rich shell pink, inclining to crimson, full double reflexed petals. Plants grow in rather compact bushy form.

Foliage always free from rust, mildew, or any defect. A ROSE FOR EVERYBODY EVERYWHERE.

Price: $\$ 1.00$ each; $\$ 7.50$ per ten.

Joaquin Miller, the Poet of the Sierras, said: "I like to go to Santa Rosa, the home of Luther Burbank, the man who is helping God make the earth more beautiful." 


\section{Nhe Luther Burbank Company}

\section{EXCLUSIVE BURBANK PRODUCTIONS}

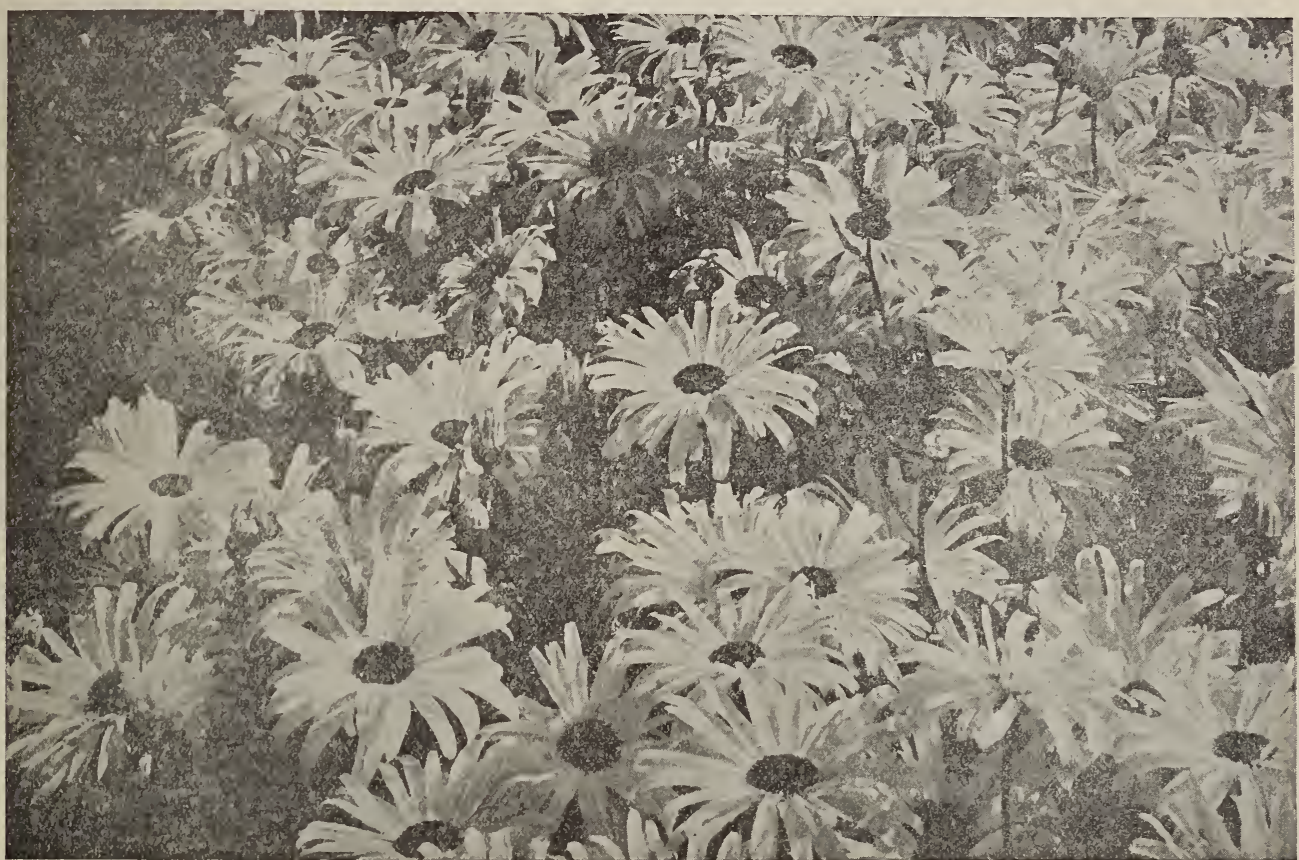

The New Improved Burbank Shasta Daisy, the "Abundance"

\section{The Burbank Shasta Daisies}

\section{New Shasta Daisies "Alaska"}

The whole plant, roots, stems, leaves, buds and flowers are gigantic, but compact and graceful in every respect.

The marvelous combination of size, grace, glistening whiteness, abundance and general effectiveness of the flowers, which are borne on long, clean, strong stems, will place it at once far ahead of all others in its class.

Under the ordinary field cultivation given Chrysanthemums, the flowers average four and a half to five inches across on stems two to three feet long, with thirty-eight to forty-two wide petals, and a very small disc, and with proper disbudding are produced perpetually, though more abundantly at the usual blooming season.

Price 40c each; $\$ 3.00$ per ten; $\$ 15.00$ per 100.

\section{"Abundance"}

The Abundance Shasta Daisy is an absolutely new variety. It is remarkable for its wonderful mass of bloom, a bed of Abundance pre- senting to the eye a mass of white, with little dots of gold here and there in the center of the flowers. This daisy is the most abundant bloomer of all known types of the daisy, without exception. This daisy in particular has excited the admiration of all who have beheld it.

The Abundance Shasta Daisy plants here offered were grown directly under the personal supervision of $\mathrm{Mr}$. Burbank and are original stock.

Price: 50 c each; $\$ 4.00$ per ten; $\$ 25.00$ per 100.

\section{"Westralia"}

The Westralia is distinguished by its branching habit, well-grown plants being one to two feet high and nearly as much through. The plants here offered are from the original stock, and are grown directly under the personal supervision of Mr. Burbank. Blossoms are four inches across, and are produced on fairly long stems in bewildering profusion.

Price: 25 c each; $\$ 2.00$ per $10 ; \$ 10.00$ per 100. 


\section{The Luther Burbank Company}

San Francisco. Cal. U.S.A.

EXCLUSIVE BURBANK PRODUCTIONS

\section{Miscellaneous Offering in Ornamental Trees, Shrubs, Etc.}

Purple-Leaved Barberry

Ornamental shrub; rich purple foliage.

Price: $75 \mathrm{c}$ each; $\$ 5.00$ per ten; $\$ 30$ per hundred.

\section{Balloon Berry \\ (Rubus —?)}

New, originally from China. Berries globular, orange color, extremely handsome, an inch or more in diameter, with large central cavity, sweet, mild and refreshing, having much the flavor of the salmon berry. Ripens before strawberries and continues for six weeks or more. For home use; too soft for market.

Price: $\$ 1.00$ each; $\$ 7.50$ per ten.

\section{Eastern Wild Black Cherry}

Very rapid upright growing tree, producing valuable lumber for cabinet work and house furnishing. Much grown for forestry and for a lawn tree. The variety offered bears unusually large fruit in unusual abundance.

Price: Select trees, $\$ 1.00$ each; $\$ 4.00$ per ten.

\section{Feijoa Sellowiana}

A beautiful evergreen fruiting shrub; closely related to the Guavas. Will stand considerable cold. Large crimson and white flowers. Produces fruit shaped like a short banana, and very delicious.
The Feijoa is not at all particular as to soil, thriving almost anywhere and withstanding severe drought and fierce winds uninjured, but like other fruits responds to good culture in the production of larger and finer fruits.

Received original stock from the Royal Gardens of the King of Italy.

A limited number of trees for sale only.

Price: $\$ 1.50$ each; $\$ 10.00$ per ten.

\section{Chinese Magnolia}

A very handsome tree which is an extra rapid grower, specially suited for shade and avenue planting.

Price: $\$ 1.00$ each; $\$ 6.00$ per ten.

\section{Mao-li-dzi}

New Chinese trailing plum from the mountains of Northwestern China. Bears fine plum guavalike fruit. Price: $\$ 1.00$ each; $\$ 7.50$ per ten.

\section{Chinese Varnish Tree}

(Rhus Verniciflua)

A unique and handsome tree well suited for lawn, shade and avenue planting.

Price: $\$ 1.00$ each; $\$ 6.00$ per ten.

\section{Yang-Tao}

(From Central China)

Similar in fruit to Mao-li-dzi, but not as hardy, large handsome foliage.

Price $75 \mathrm{c}$ each; $\$ 5.00$ per ten.

\section{Miscellaneous Plants and Flowers Burbank Productions Grown Directly from the Original Stock}

These plants are field grown and are very thrifty and hardy. Greater success and much quicker results are obtained from properly grown plants than from seed. Price includes packing and delivery charges, unless otherwise specially noted.

\section{Campanula Rotundifolia Alba (Blue Bells of SCOTland) (WHITE VARIETY.)}

This is the blue bell of romance and found on three continents. Dainty bell-like flowers growing on long delicate stems which sway with every breeze. Beautiful white instead usual blue flowers.

Price: Plants 25c each; $\$ 2.50$ per dozen.

\section{Canna- "Tarrytown"}

The Burbank strain of Cannas is too well known to need particular comment. The Canna "Tarrytown" is a bright crimson canna and has received awards as being the freest of bloomers. These cannas are summer bloomers and a bed of the "Tarrytown" resembles a mass of flame. The blooming period extends through the summer until early autumn. They are extremely hardy and need but little attention, producing very satisfactory results. The foliage of the Canna "Tarrytown" is large and dark green; and when not in bloom forms an ornamental cluster or clump.

Price: Bulbs, $25 \mathrm{c}$ each; $\$ 2.00$ per dozen.

\section{Carnations Marguerite} (Burbank Strain.)

The colors are deep crimson, crimson, light crimson, rose, pink, clear pink, light yellow, and striped. This strain is very unusual in the fact that it blooms the first year, which is not so with most kinds. These carnations are dwarfed, early bloomers, and are varieties which $\mathrm{Mr}$. Burbank has produced and re-selected for years 


\section{The Luther Burbank Company}

\section{EXCLUSIVE BURBANK PRODUCTIONS}

with the idea of increasing the size, the abundance of bloom and fragrance, and in all these particulars they are unsurpassed by any carnation of its class.

Price: Plants 15c each; \$1.25 per dozen.

\section{Coreopsis Golden Wave}

Huge daisy-like flowers of golden yellow grown in great masses. Are especially desirable either for bedding or as a border plant. Its blooming period is long, extending from quite early in the summer until late autumn. The flowers are about two inches across, the general growth being very compact and hardy.

Price: Plants 20c each; $\$ 2.00$ per dozen.

\section{Coreopsis Lanceolata Grandiflora}

(Burbank Strain.)

It is a perennial, with light graceful foliage, producing great quantities of handsome gold and yellow flowers all summer. The long stems make them specially desirable for cutting. It is a very free bloomer and it is quite hardy.

Price: Plants 20c each; $\$ 2.00$ per dozen.

\section{Gaillardia Grandiflora}

(EXTREMELY LARGE, VARIOUS COLORS)

Beautiful large flowering perennials, remarkable for size and profusion of bloom. Flowers shading from brown to crimson and orange to yellow. Very effective. Blooms all summer.

Price: Plants 25c each; $\$ 2.50$ per dozen.

\section{Hollyhock}

\section{(Chaters Best Double Mixed)}

Too well known to need detailed description. Easily raised from seed sown in the early spring. Valuable for a background.

Price: Plants 25 c each; $\$ 2.50$ per dozen.

\section{Burbank's New Gigantic Evening Primrose}

\section{(OEnothera America.)}

This is by far the largest of all the evening primroses, one single petal being as large as the whole flower of most other varieties of primroses.

The blossoms are pure white, sometimes nearly a foot and a half in circumference, perfectly regular and flat. The effect of a field of them at once suggests a lawn covered with snow white napkins. Mr. Burbank says as far as known, with the exception of his Shasta Daisies, no hardy plant bearing snow-white flowers produces such a wealth of enormous blossoms and continually for months in succession as his new Gigantic Evening Primrose. Grown with the ut- most ease and is suited with almost any soil. Any ordinary heavy frost has no effect on the plant.

Price: Plants 20c each; $\$ 2.00$ per dozen.

\section{Platycodon Mariesi}

(JAPANESE BALLOON FLOWER)

This is a dwarf variety of the large flowering lavender blue Japanese balloon flower, plants being about one foot high. The flower is three inches across, saucer-shaped, and is mostly blue, although sometimes white. It is not attacked by pests and is very healthy and has often nearly one hundred blossoms to each plant. Blooms from middle of July for six weeks. A beautiful plant not widely known.

Price: Plants 20c each; $\$ 2.00$ per dozen.

\section{Passion Flower}

\section{(The Australian Fruiting.)}

The Passion Flower bears delicious fruit in abundance. Is semi-hardy and will not withstand very cold temperature. Perennial and will climb or make a bush as desired. Highly prized for its fruit. Purple; size and shape of a large hen's egg.

Price: 15 c each; $\$ 1.25$ per dozen.

\section{Lippia Repens for Lawns}

Two new forms never before available.

The Lippias are closely related to the Lantanas and the Verbenas and include a number of plants quite dissimilar in appearance. It is a low, spreading plant, having a habit of rooting from runners when originally started from plant or seed. It forms a thick mass and has great value for lawns, requiring as it does only about one-tenth the care and one-tenth the water needed for any other lawn. They make a most beautiful dark green close-growing lawn. These varieties will produce a close rich dark green lawn in six weeks if planted during the warm summer months, and will keep in good condition longer than any blue grass or clover lawn and with one-tenth the care, water, weeding, mowing and other expenses which the ordinary lawn requires.

No. 1. "Dixie"- This makes a most beautiful dark green close-growing lawn. The foilage is very small, closely placed on slender stems and is of a pleasing glossy, dark green color.

No. 2. "Mohave"-The foliage is light green, larger and more rapid grower than the other Lippias.

Price: Dixie, 10 foot square $\$ 2.00 ; 40$ plants $\$ 1.00$. Mohave, 10 foot square $\$ 1.50$; 40 plants $75 \mathrm{c}$. 


\section{The Luther Burbank Company \\ San Francisco. Cal. U. S.A.}

\section{FRUIT DEPARTMENT Standard Varieties}

\section{(For Burbank Productions See Previous Pages)}

A careful selection of the better standard varieties of fruits has been made by our experienced nurserymen with the result that practically all of the worth-while standard sorts are here listed.

We carry, however, in addition to the varieties enumerated, a complete assortment of all kinds of fruits and berries and if particular needs are not covered by this catalog, quotations, descriptions, and all information as to any non- listed varieties will be gladly furnished on application.

Our prices will be found exceedingly reasonable. Only stock of the high Burbank standard is handled, backed by this Company's guarantee.

In ordering please refer to "Order and Shipping Instructions" contained on another page. Caliper measurement will in some cases supplement height in grading trees.
APPLES. 4-6 ft., $25 \mathrm{c}$ each; $\$ 2.00$ for 10 .

\section{“6 $3-4 \mathrm{ft} ., 20 \mathrm{c}$ each; $\$ 1.80$ for 10.}

Alexander-Large yellow streaked red. Ripens September.

Baldwin-Deep red. Ripens Nov. to Feb.

Delicious-Dark red with splashes of yellow. Ripens. Nov.

Gravenstein-Large striped red and orange. Ripens Aug.

$\checkmark$ Winter Banana-Large pale yellow, pink blush. Ripens Nov.

Red Astrachan-Deep crimson. Ripens July.

Yellow N. Pippin-Large golden yellow, ripens Jan. to May.

Rome Beauty-(One of the most popular varieties in California)-Yellow striped red. Ripens Nov. to Feb.

Jonathan-Yellow with red stripes. Ripens Oct. to Dec.

$\checkmark$ Wagner-Deep red, excellent quality. Ripens October.

CRAB APPLES. Same price as Apples.

$\checkmark$ Red Siberian-Yellow with scarlet cheek. Ripens Sept.

$\checkmark$ Transeendent - Large yellow striped red. Ripens Sept.

Yellow Siberian-Beautiful golden yellow. Ripens Aug.

APRICOTS. $\quad 1$ yr. $4-6 \mathrm{ft} ., 40 \mathrm{c}$ each; $\$ 3.50$ for 10 "، $3-4 \mathrm{ft}$., $35 \mathrm{c}$ each; $\$ 3.00$ for 10 "6 $2-3 \mathrm{ft}$., $30 \mathrm{c} \mathrm{each;} \$ 2.50$ for 10

Blenheim-Medium. Deep yellow, juicy and rich flesh. Heavy bearer. Ripens June (middle).

Hempskirk-Almost as large as Moorpark. Flesh bright orange. Ripens June (late).

Royal-The most extensively planted variety. Flesh pale orange. Ripens June (early).

Moorpark-Very large. Fresh bright orange. ripens June (late).
CHERRIES. 1 yr. $4-6 \mathrm{ft} ., 35 \mathrm{c}$ each ; $\$ 3.00$ for 10 "6 $3-4 \mathrm{ft}$., $30 \mathrm{c}$ each; $\$ 2.50$ for 10 "، $2-3 \mathrm{ft}$, $25 \mathrm{c}$ each; $\$ 2.00$ for 10

Bing-One of the grandest blacks. Large size, delicious flavor. Tree strong grower. Ripens middle of June.

Black Tartarian-An old favorite. Deep purplish black. Ripens May.

Chapman-Black. Very firm. Good early variety, ripens April and May.

$\sqrt{ }$ Governor Wood-Deep yellow, shaded red. Ripens June (early part).

$\checkmark$ Lambert-Large size. Rich, glossy deep red. Ripens middle of June.

$\sqrt{ }$ Royal Ann-A magnificent cherry. Pale yellow with bright red cheek, flesh firm and sweet. Ripens June (late).

PEACHES. $1 \mathrm{yr}$. $4-6 \mathrm{ft}$., $30 \mathrm{c} \mathrm{each}$; $\$ 2.50$ for 10 "6 $3-4 \mathrm{ft} ., 25 \mathrm{c}$ each; $\$ 2.00$ for 10 2-3 ft., $20 \mathrm{c}$ each; $\$ 1.80$ for 10

Alexander-Peach large greenish white, shaded deep maroon. Sweet. Ripens June (early).

$\checkmark$ Early Crawford-Very large. Flesh yellow. Ripens July (middle).

Foster - Large yellow. Resembles Early Crawford, but ripens earlier. Ripens July.

$\sqrt{ }$ Late Crawford-Very large. Flesh deep yellow. Juicy and melting. Ripens Aug. (late).

$\checkmark$ Muir-A fine large fruit. Flesh yellow. Excellent for canning. Ripens Aug.

Phillips Cling- The best late clingstone. In great demand by the canneries.

Elberta-One of the best varieties for all purposes. Ripens July (late).

PEARS. $1 \mathrm{yr}$. 4-6 ft., $50 \mathrm{c}$ each; $\$ 4.00$ per 10

"، 1 yr. 3-4 ft., $40 \mathrm{c}$ each; $\$ 3.00$ for 10

، $\quad 2-3 \mathrm{ft} ., 30 \mathrm{c}$ each; $\$ 2.50$ for 10

Bartlett-Large golden yellow, red cheek. (the leading commercial pear). Ripens Aug. 


\section{FRUIT DEPARTMENT \\ Standard Varieties}

$\checkmark$ Peter Barry-Fruit yellow. Fine grained. Excellent keeper. Ripens Dec. to Mar.

Burre Clairgeau-Large crimson. Good shipper. Ripens Sept.

$\checkmark$ Winter Bartlett-Almost identical with Summer Bartlett. Ripens Nov.

Winter Nelis-Flesh yellowish white. Excellent shipper. Ripens Dec.

Easter Burre-Large pale yellow. One of the best late pears. Ripens Oct. to June.

PLUMS. (See Burbank Plums Ante).

PRUNES. $1 \mathrm{yr} . \quad 4-6 \mathrm{ft}$., $50 \mathrm{c}$ each; $\$ 4.00$ for 10

" $3-4 \mathrm{ft} ., 40 \mathrm{c}$ each; $\$ 3.00$ for 10

$3-4 \mathrm{ft} ., 40 \mathrm{c}$ each; $\$ 3.00$ for 10
2 - 3 t., $30 \mathrm{c}$ each; $\$ 2.50$ for 10

French-Medium size. Purple, sweet and rich. Standard for drying. Ripens Aug.

German-Long purple. Flesh green, sweet, freestone. Ripens Aug.

Hungarian-Ređdish violet. Juicy and sweet. Vigorous grower. Ripens Aug.

$\checkmark$ Silver-Fruit pale yellow. Fine for canning. Ripens Sept.

Tragedy-Dark purple. Flesh green. Very rich and sweet. Ripens July (early).

QUINCES. 4-6 ft., 35c each; $\$ 3.00$ per 10. "6 $3-4$ ft., 30 c each; $\$ 2.50$ for 10 .

Apple or Orange-Large, fine golden color. Ripens Sept.

Champion-Excellent quality. Ripens Sept.

Pineapple-(Described elsewhere).

\section{NUTS}

ALMONDS. $1 \mathrm{yr} . \quad 4-6 \mathrm{ft} ., 40 \mathrm{c} \mathrm{each} ; \$ 3.00$ for 10 . " $\quad 3-4 \mathrm{ft} ., 30 \mathrm{c}$ each; $\$ 2.50$ for 10. $2-3 \mathrm{ft} ., 25 \mathrm{c}$ each; $\$ 2.00$ for 10 .

IXL-The nuts are large, soft shell. Tree sturdy grower and a good cropper.

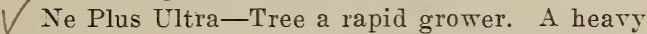
bearer. Nuts long, sweet and soft shell.

Nonpareil-Nuts of the paper shell type. Excellent bearer.

Texas Prolific-Tree a late bloomer and prolific bearer.

WALNUTS. Grafted on California black root.

Franquette-Nut is large oral shape. Full, sweet and of a rich flavor. 4-6 ft., \$1.50 each.

Mayette-Tree an abundant bearer and late bloomer. Unequaled as a dessert nut. 4-6 ft., $\$ 1.50$ each.

\section{CITRUS}

ORANGES. $\quad 4-5$ ft., $\$ 2.00$ each; $\$ 18.00$ for 10 .

Riverside Washington Naval-Fruit first-class in every respect. Oral, smooth, seedless,

pulp fine grained, flavor excellent.

Valencia Late-Large fruit, ripening when most all other varieties are gone.

LEMONS. 4-5ft., \$2.00 each; $\$ 18.00$ for 10 .

$\checkmark$ Eureka-Medium size, sweet. Very popular on account of its heavy summer crop.
Lisbon-Medium size, very strong acid; few seeds. A prolific bearer.

POMELOS. 4-5 ft., $\$ 2.00$ each.

Marsh's Seedless-The finest variety of Pomelo. The fruit will hang on the trees till late in September.

Special selected trees, $\$ 2.50$ each.

FIGS. 4-5 ft., $40 \mathrm{c}$ each; $\$ 3.00$ for 10 .

$3-4 \mathrm{ft} ., 30 \mathrm{c}$ each; $\$ 2.50$ for 10 .

$2-3 \mathrm{ft} . .25 \mathrm{c}$ each $; \$ 2.00$ for 10 .
California Black-Fruit large, dark purple, al-

most black when ripe.

White Adriatic-Fruit greenish Jellow; pulp red.

$\checkmark$ Calimyrna-Fruit large. Skin lemon yellow; pulp reddish amber. Must be fertilized by the Blastophagus Wasp.

$\checkmark$ Capri or Wild-Must be grown near the Calimyrna Fig, as this variety contains the male flower, whose pollen is necessary for the fertilization of female flowers found on the edible fig.

Capri: $50 \mathrm{c}$ each.

GRAPES. 20c each; $\$ 1.50$ for 10 .

For table and raisins.

California Black-The well-known mission grape.

Tokay-Flame Tokay-A magnificent large red grape.

$\checkmark$ Muscat of Alexandria-One of the best. Bunches large, fruits amber color.

Thompson's Seedless-An enormous bearer bunches very large; berries greenish-yellow; seedless. A raluable shipping grape.

\section{AMERICAN GRAPES.}

Agawam-One of the best red rarieties.

Concord-Bunches large and compact; berries large, sweet and red.

Isabella-Berries oval, juicy and sweet. An imimense bearer. Black.

Other varieties may be had on application.

\section{BERRIES}

(For Burbank Berries, See Ante)

LOGAN BERRIES. A cross between the blackberry and the raspberry. Partakes of the flavor of both raspberry and blackberry.

Fruit very large, excellent for table and makes fine jelly or jam.

15 c each; $\$ 1.00$ for $10 ; \$ 6.00$ for 100 .

MAMMOTH BLACKBERRY. Deep red, rery productive, with unusually large, early fruits.

1 če each; $\$ 1.00$ for $10 ; \$ 6.00$ for 100 .

CURRANTS. Strong, 2-year-old plants, $25 \mathrm{c}$ each; $\$ 2.00$ for 10 .

$\checkmark$ Black Naples-Berries large and black.

$\sqrt{ }$ Cherry Currant-Very large, deep red.

Fay's Prolific-Very productive, with large, rich, red-colored fruits.

RASPBERRIES. $75 \mathrm{c}$ for 10 .

VCuthbert-Very large and handsome. Bears transportation well. Very productive. 


\section{Standard Varieties}

The offering of high class ornamentals listed is made only after a rigid selection which elim. inated certain less desirable varieties and species. All stock is the best that can be grown and guaranteed of Burbank Standard.

\section{EVERGREEN TREES AND SHRUBS}

(For Burbank Ornamentals, See Ante)

ACACIA. Flowering trees or shrubs of varying habit, appearance and foliage.

Mollissima-One of the finest acacias, with dark green, feathery foliage. Flowers yellow, appearing in spring.

Price: $3 \mathrm{ft} ., 40 \mathrm{c}$ each $; \$ 3.50$ per 10.

4-5 ft., $60 \mathrm{c}$ each; $\$ 5.00$ per 10 .

$5-6 \mathrm{ft}$., $75 \mathrm{c}$ each; $\$ 6.00$ per 10.

Melanoxylon-A strong grower, one of the best for parks and street ornamentation.

Price: $\quad 4-5 \mathrm{ft} ., 50 \mathrm{c}$ each; $\$ 4.50$ per 10 . 6-7 ft., 75c each; $\$ 6.00$ per 10 .

Floribunda-A beautiful tree of pendulous habit, with long, narrow leaves and bright yellow flowers.

Price. $\quad 4-5 \mathrm{ft.}, 50 \mathrm{c}$ each; $\$ 4.50$ per 10 . $6 \mathrm{ft} ., 75 \mathrm{c}$ each; $\$ 7.00$ per 10 .

Armata - A spreading shrub with yellow flowers, excellent for grouping.

Price: $60 \mathrm{c}$ and $75 \mathrm{c}$ each.

Latifolia-Of spreading habit, valuable for grouping; long, glossy, green leaves; flowers golden-yellow.

Price: $\quad 4-5 \mathrm{ft} ., 60 \mathrm{c}$ each $; \$ 5.00$ per 10

$6 \mathrm{ft} ., 75 \mathrm{c}$ each; $\$ 7.00$ per 10 .

Resiana-A variety with heath-like foliage, producing clusters of beautiful yellow flowers.

Price: $75 \mathrm{c}$ each.

Baileyana-Foliage beautiful sea green; flowers, yellow ball-shaped; very free flowering. Price: $3-4 \mathrm{ft} ., 75 \mathrm{c}$ each.

4-5 ft., $\$ 1.00$ each.

We also carry numerous other varieties of this beautiful evergreen.

AUCUBA Fine shrubs with shining dark green foliage and conspicuously dotted with spots. Price: Potted plants from 50c to $\$ 3.00$ each.

AZALEA INDICA. Well-known small, compact shrubs, flowering about Easter.

Potted: $\$ 1.50$ to $\$ 2.50$ each.

ARAUCARIA. Fine ornamental trees, useful for lawn specimens.

Bidwilli-Potted, 1 to $11 / 2 \mathrm{ft}$., $\$ 1.50$ to $\$ 2.00$ each.

Imbricata-Potted, $3 \mathrm{ft}$., $\$ 6.00$ each.

BOX. (Buxus). Shrubs of compact dense growth; can be trimmed into almost any form.

Dwarf-For edging, per $100, \$ 4.00$.

Tree Form-In pot or tubs, trimmed, $\$ 2.50$ to $\$ 10.00$ each.

BROOIM. (Cytisus). Free flowering shrub; blossom, pea-shaped. $50 \mathrm{c}$ each.

CAMELIIA. Beautiful shrubs with dark glossy foliage and large wax-like flowers.

According to size: $\$ 1.00, \$ 2.00$ and $\$ 3.00$ each.

COPROSIMA. Low-growing shrub, with wonderfully glossy foliage.
Special desires for varieties not listed will be readily met upon application. The advice and consultation of our expert landscape engineer may be had by any customer without charge. In pots: $1 \mathrm{ft} ., 50 \mathrm{c}$ and $75 \mathrm{c}$ each.

COTONEASTER. Pretty evergreen shrubs producing numerous red berries.

In pots: $50 \mathrm{c}$ and $75 \mathrm{c}$ each.

CAMPHOR. (Laurus Camphora). Beautiful tree with bright green foliage well adapted for lawns.

Price: $3-4$ ft., $\$ 1.00$ and $\$ 1.25$ each.

CASSIA. Ever-flowering shrub, produces yellow flowers in great profusion.

Price: 2 to $2 \frac{1}{2} \mathrm{ft}$., $35 \mathrm{c}$ and $50 \mathrm{c}$ each.

CEDAR. (Cedrus Deodora). Queen of evergreens.

Price: $2-3 \mathrm{ft} ., \$ 1.00$ each.

3-4 ft., $\$ 1.50$ to $\$ 6.00$ each.

CESTRUM. Free-flowering evergreen shrub continuously covered with orange-colored flowers.

Price: $11 / 2$ to $2 \mathrm{ft}$, $50 \mathrm{c}$ each.

CHOISYA. (Ternata.) Fine shrub, with glossy green foliage and abundant sweet-scented flowers.

Price: 1-2 ft., $75 \mathrm{c}$ and $\$ 1.00$ each.

DAPHNE. Glossy foliage and rich, fragrant flowers.

Price: White, $11 \frac{1}{2} \mathrm{ft} ., \$ 1.00$ and $\$ 1.25$ each.

Pink, $11 / 2$ ft., $\$ 1.00$ and $\$ 1.25$ each.

DIOSMA. (Breath of Heaven). Foliage, heathlike; agreeably fragrant; small white flowers. Price: $50 \mathrm{c}$ each.

CYPRESS. (Cupressus). This includes numerous varieties well adapted to California planting.

Prices according to variety and size.

EUCALYPTUS. More extensively planted in California than all other trees combined. Valuable timber tree noted for its rapid growth. We carry numerous varieties.

Ficifolia. (Scarlet flowering). $-21 / 2-3 \mathrm{ft}$., $75 \mathrm{c}$ to $\$ 1.00$ each.

Globulus-5-6 ft., 25c each; $\$ 2.00$ for 10 .

Rostrata-4-5 ft., 25c each; $\$ 2.00$ for 10.

EUONYMOUS. Handsome shrub with glossy foliage.

Price: $50 \mathrm{c}$ and $75 \mathrm{c}$ each.

GREVILLEA. Very graceful, fern-like leaves, with bronze-yellow flowers.

Price: 3-4 ft., $50 \mathrm{c}$ each.

5-6 ft., 75c each.

$7-8 \mathrm{ft} ., \$ 1.50 \mathrm{each}$.

HOLLY. (Ilex.) A small tree; shining, dark green, thorny leaves and red berries.

Price: Balled, $2-3 \mathrm{ft}$., $\$ 3.00$.

Balled, 3-4 ft., $\$ 4.00$.

Balled, 4-5 ft., $\$ 5.00$.

HABROTHAMNUS. (Coral Plant). Stronggrowing shrub, purplish trumpet-shaped flowers.

Price: 2-3 ft., 50c and $60 \mathrm{c}$ each. 


\section{The Luther Burbank Company}

\section{ORNAMENTAL DEPARTMENT \\ Standard Varieties}

LAUREL Shining leaves; clusters of creamywhite flowers.

English-Boxed, 21/2 to $3 \mathrm{ft}$., $\$ 2.75$ each.

Portugal-Boxed, $11 / 2$ to $2 \mathrm{ft}$., $\$ 1.25$ each.

Sweet Bay-Trimmed in pots and tubs. Prices ranging from $\$ 1.00$ to $\$ 50.00$ each, according to size.

LEPTOSPERNUM. Tall graceful shrub. Foliage grayish, with white flowers. Price: $21 / 2$ to $3 \mathrm{ft}$., $50 \mathrm{c}$ each.

LIGUSTRUM. (Privet). A valuable hedge plant; stands pruning well and is of rapid growth.

Price: $21 / 2-3$ ft., 20 e each; $\$ 1.50$ per 10 ; $\$ 12.00$ per 100 .

Elegantissima Aurea-2-21/2 ft., $75 \mathrm{c}$ each.

LAURUSTINUS, Ornamental plant with au abundance of white flowers in winter.

Price: In pots, $1 \mathrm{ft}$., $25 \mathrm{c} \mathrm{each}$.

In pots, $11 / 2 \mathrm{ft}$., $35 \mathrm{c}$ each.

METROSIDEROUS. (Bottle Brush). Narrow leaves and rich erimson flowers in July. 50c and $75 \mathrm{c}$. each.

MAGNOLIA. One of the best of broad-leaved evergreens, with fragrant flowers 10 to 12 in. across.

Price: According to size, $\$ 1.50, \$ 2.00$ and $\$ 3.00$ each.

MYRTLE (Myrtus). Dwarf shrubs, lustrous green leaves, fragrant white flowers.

Prices: 6-in. pots, $50 \mathrm{c}$ and $75 \mathrm{c}$ each.

OLEANDER (Nerium). One of the best of ever-blooming evergreens.

Prices: Double white, $2 \mathrm{ft.}, 75 \mathrm{c}$ and $\$ 1.00$ each. Double pink, $2 \mathrm{ft} ., 75 \mathrm{c}$ and $\$ 1.00 \mathrm{each}$.

PITTOSPORUM. Highly ornamental, fine for hedge or planted as single specimen.

PITTOSPORUM EUGENOIDS. 2-3 ft., $35 \mathrm{c}$; $\$ 3.00$ per 10 .

PITTOSPORUM NIGRICANS. 2-3 ft., 35c; $\$ 3.00$ per 10 .

PEPPER TREE. (Schinus Molle). Forms a beautiful shade tree, with fern-like pendant foliage.

Price: 4 in. pots, $2-3 \mathrm{ft}$., $40 \mathrm{c} \mathrm{each}$.

$3-4 \mathrm{ft}$., $50 \mathrm{c}$ each.

4-6 ft., $60 \mathrm{c} \mathrm{each}$.

PINE. (Pinus). An important timber tree, also valuable for massing in parks and gardens.

Monterey -2 to $3 \mathrm{ft} ., 50 \mathrm{c}, 75 \mathrm{c}$ and $\$ 1.00 \mathrm{each}$.

VESUVIUS PLUM. (See Burbank Productions).

RETINOSPORA. (Japan Cypress). Pretty dwarf tree. Foliage bright green above, glancuous beneath.

According to size, $\$ 1.00$ to $\$ 6.00$ each.

ROMINEYA COULTERII. (Matilija Poppy). Beautiful poppy with pure white flowers and yellow stamens. Deliciously perfumed.

Price: 4 in. pots, $\$ 1.50 ; 6$ in. pots, $\$ 2.00$ each.

RAPHIOLEPIS. Compact growing shrub, dark green foliage and white flowers.

Price: Boxed, 11/2 $\times 2 \mathrm{ft} ., 85 \mathrm{c}$ and $\$ 1.00$ each. In pots, $60 \mathrm{c}$ each.

SPRUCE. (Abies). Amongst these will be found some of the best coniferous trees in existence.
Price: According to variety and size, $\$ 1.00$ to $\$ 10.00$ each.

SCIADOPITYS. (Umbrella Pine). A fine lawn tree, leaves deep green in regular whorls. Price: In pots or tubs, $\$ 2.50$ to $\$ 8.00$ each.

VERONICA. Small shrubs with various colored flowers. Fine for grouping.

Price: According to size and variety, 50e and $75 \mathrm{c}$ each.

YEW. (Taxus). Very desirable for park planting; densely clothed with dark green foliage.

English- $\$ 1.00$ to $\$ 5.00$.

Irish $-\$ 1.00$ to $\$ 5.00$.

Variegated- $\$ 1.00$ to $\$ 5.00$.

CLIMBING AND TRAILING PLANTS

AMPELOPSIS. (Veitchii and Quinquefolia). A rapid growing vine. The leaves are handsome and luxuriant, assuming in autumn a gorgeous bronze hue.

Price: Strong plants, $50 \mathrm{c}$ to $75 \mathrm{c}$ each.

BOUGAINVILLIA. A good, strong climber, producing an abundance of rosy-colored flowers in great profusion.

Price: Strong plants, $75 \mathrm{c}, \$ 1.00$ and $\$ 1.25$.

CLEMATIS. The Clematis is slender-branched climbers, with large and beautiful flowers of various colors. Price: $50 \mathrm{c}$ and $75 \mathrm{c}$ each.

FICUS REPENS. A very pretty climber; clings to the wall or wooden surface without assistance.

Price: $25 \mathrm{c}$ and $50 \mathrm{c}$ each.

HONEYSUCKLE. A strong, vigorous climber with an abundance of fragrant flowers.

Price: Pot-grown, 50c each.

JASMINE. Plants bearing star-shaped, fragrant flowers, which are produced in great profusion.

Price: Yellow, 50c and $75 \mathrm{c}$ each.

White, $50 \mathrm{c}$ and $75 \mathrm{c}$ each.

LOTUS PELIORYNCHUS. A dainty plant of creeping habit, with masses of scarlet flowers.

Price: $35 \mathrm{c}$ and $50 \mathrm{c}$ each.

MANDEVILLEA SUAVEOLENS. Strong climb. er, flowers very fragrant, star-shaped. Price: Strong plants, $50 \mathrm{c}$ and $75 \mathrm{c}$ each.

MUEHLENBECKIA. (Mattress Vine). Fine for covering old stumps of trees, rockwork, ete. Price: Pot-grown, 2-3 ft., 50c and 75c each.

PASSION VINE. Well-known, hardy climbers, covered with large, handsome flowers.

Price: Pink, 35c and 50c.

Scarlet, $35 \mathrm{c}$ and $50 \mathrm{c}$.

PLUMBAGO CAPENSIS. Can be trained as bush or climber. Flowers sky-blue, very free.

Price: $11 / 2-2 \mathrm{ft} ., 35 \mathrm{c}$ and $50 \mathrm{c}$.

RHYNCHOSPERIMUM JASIMANOIDES. The flowers are small, star-shaped, borne in profusion and deliciously fragrant.

Price: $25 \mathrm{c}$ and $75 \mathrm{c}$ each.

SOLANUM JASMANOIDES. Very rapid climber; the flowers are star-shaped and borne in large clusters.

Price: Pot-grown, 50c each. 


\section{The Luther Burbank Company}

San Francisco. Cal. U.S.A.

ORNAMENTAL DEPARTMENT

\section{Standard Varieties}

WISTERIA. Deciduous vines of rapid growth. Flowers pea-shaped in long drooping racemes in early spring.

Grafted 2 to 3 years.

Chinensis Purple-Flowers in clusters about a foot long.

Price: According to size, $\$ 1.00$ to $\$ 2.50$ each.

Chinensis Alba-Similar to the above variety, but has pure white blossoms.

Price: $\$ 1.00$ to $\$ 2.50$ each.

Japanese Double Purple (New)-Fine, large, double flowering variety of rapid growth. Price: $\$ 1.50$ to $\$ 2.00$ each.

Pink Perfection-A beautiful pink variety, very rare.

Price: $\$ 1.25$ each; extra strong plants $\$ 2.00$ each.

Price: Large specimen plants, $\$ 5.00$ and $\$ 7.00$ each.

ORNAMENTAL DECIDUOUS TREES

AIMOND. (Amygdalus). Flowering in early Spring.

Price: Double white, $2-3 \mathrm{ft} ., 60 \mathrm{c}$

Double pink, $2-3 \mathrm{ft} ., 60 \mathrm{c}$.

BEFCH. (Fagus). Beautiful trees with glossy green foliage.

European-Price: $75 \mathrm{c}$ to $\$ 1.50$ each.

Purple-Leaved-Price: $\$ 1.00$ to $\$ 4.00$ each.

Tri-Color-Price: $10 \mathrm{in}$. pots, $4-5 \mathrm{ft} ., \$ 4.00 \mathrm{each}$.

BIRCH. (Betula). A rapid-growing tree with silvery white bark, drooping branches.

European White-Price: 7-9 ft., \$1.00 each. Price: 10-12 ft., $\$ 1.50$ each.

European White-Cut-leaved. Price: 4-5 ft., $50 \mathrm{c}$ and $75 \mathrm{c}$ each.

CATALPA. Very ornamental tree, white flowers and large heart-shaped foliage. Price: 6-7 ft., 75c and $\$ 1.00$ each

ELDER. (Golden). Beautiful golden foliage. Price: $3-4 \mathrm{ft}$., $75 \mathrm{c}$.

ELM. (Ulmus). Very extensively used for avenue planting.

American White-Price: 4-5 ft., 50c; 6-8 ft., $75 \mathrm{c}$ and $\$ 1.00$.

English-Price: 4-5 ft., 50c; 6-8 ft., $75 \mathrm{c}$ and $\$ 1.00$ each.

EMPRESS TREE. (Paulownia). Enormous round leaves and purple flowers. Price: 5-6 ft., $75 \mathrm{c} ; 6-8 \mathrm{ft} ., \$ 1.00 \mathrm{each}$.

KOLREUTERIA. (Varnish Tree). Small tree with glossy foliage and yellow flowers. Price: 4-6 ft., 60e each.

IINDEN. (Tilia). Shapely trees with handsome foliage.

European-Price: $6-8 \mathrm{ft.}, 75 \mathrm{c} ; \$ 7.00$ per 10 .

American-Price: 6-8 ft., 75c; $\$ 7.00$ per 10 .

LOCUST. (Robinia). Very ornamental trees, with an abundance of flowers.

Black-Price: $6-8 \mathrm{ft}$., $60 \mathrm{c} ; \$ 5.00$ per 10 .

Pink Flowering-Price: $6-8 \mathrm{ft} ., 75 \mathrm{c} ; \$ 6.50 \mathrm{per}$ 10.

Rose Flowering-Price: 4-6 ft., $\$ 1.00$ each.

MAGNOLIA. (Conspicua.) A free bloomer with large white flowers. Price: 5-6 ft., $\$ 2.00, \$ 2.50$ each.

MAPLE. (Acer). A fine shade tree, valuable for park and street planting.

Silver-Price: 6-8 ft., 75c; \$6.00 per 10.
Norway-Price: 6-8 ft., 75c; $\$ 6.00$ per 10 .

California-Price: 5-6 ft., 60c; $\$ 5.00$ per 10.

Schwedler's Purple-Price: 4-6 ft., \$1.00 each.

MOUNTAIN ASH. (Sorbus). Ornamental trees with white flowers, followed by brilliant red berries.

Price: 6-7 ft., $75 \mathrm{c}$ each.

PEACI FIOWERING. (Persica). The doubleflowering varieties are distinguished for their highly-colored, beautiful bloom. Price: Double white, $4-5 \mathrm{ft} ., 50 \mathrm{c}$ each. Price: Double pink, $4-5 \mathrm{ft}$., $50 \mathrm{c}$ each.

PLUM. (Prunus). Medium-sized trees with purple foliage, very ornamental.

Pissiardii-Price: $4-6 \mathrm{ft} ., 50 \mathrm{c}$ each.

Vesuvius-Burbank's rich metallic, crimson foliage with crumpled surface. Price: $75 \mathrm{c}$ each.

SYCAMORE. (Platanus). Erect-growing tree with handsome green foliage.

Orientalis-Price: $7-8 \mathrm{ft.}, \$ 1.00 \mathrm{each}$

THORN. (Crataegus). A small tree with spreading branches and beautiful flowers.

Price: Double White, 5-6 ft., 75c each.

Price: Double Scarlet, 5-6 ft., $75 \mathrm{c}$ and $\$ 1.00$ each.

DECIDUOUS SHRUBS

FLOWERING CRAB. (Pyrus). Low - growing admirable for lawn trees, or shrubberyplanting.

Betchells-Price: 3-4 ft., $75 \mathrm{c}$ each.

Floribunda-Price: $75 \mathrm{c}$ each.

Spectabilis-Price: $75 \mathrm{c}$ each.

BARBERRY. (Berberis). A pretty shrub with handsome foliage and berries.

Price: 21/2 ft., 35c ea،h; $\$ 3.50$ per 12 .

Atropurpurea-Price 50c each; $\$ 4.00$ per 10 .

HYDRANGEA. (Paniculata). The flowers are white and are produced for a long period during summer and fall. Price: $50 \mathrm{c}$ each.

Hortensis-Pink, enormous trusses of flower. Price: $50 \mathrm{c}$ and $75 \mathrm{c}$ each.

DEUTZIA CRENATA. Produeing double white flowers. Price: $2-3 \mathrm{ft}$., $50 \mathrm{c}$ each; $\$ 4.00$ per 10 .

LEMON VEPBENA. A favorite shrub with longpointed leaves, which emit a delightful fragrance. Price: $40 \mathrm{c}$ each.

LII.AC. Grafted, assorted colors. Price: Named varieties, 3-4 ft., 75c each.

MOCK ORANGE. (Philadelphus.) Flowers pure white, with delightful fragrance. Price: 50c each.

QUINCE. (Cydonia): Red flowers appearing before the leaves. Price: $50 \mathrm{c}$ each.

SNOWBAIL. (Viburnum). Produces an abundance of pure white flowers. Price: 50e each.

SPIREA. Free-flowering shrubs of easy culture. Price: $2-3 \mathrm{ft}$., $50 \mathrm{c}$ each; $\$ 4.00$ per 10 .

TAMARISC. Handsome flowering tree thriving in all soils. Price: 3-4 ft., $50 \mathrm{c}$ each.

WIEGELIA. (Diervilla). Free-flowering shrubs, assorted colors in variety. Price: 2-3 ft., $50 \mathrm{c}$ and $60 \mathrm{c}$ each. 


\section{ROSE DEPARTMENT Standard Varieties}

(For Burbank Productions, See Ante).

We also carry a number of varieties not contained in this list, description and prices of which will be furnished on application.

NEW ROSES OF RECENT INTRODUCTION MRS. GEORGE SHAWYER. A pink rose of charming tone, perfect form, A producer of lovely flowers. One of the recent introductions.

Price: 4 in. pots., $75 \mathrm{c}$ each; $\$ 7.50$ per 12 .

MRS. CHAS. RUSSELL. A rery late introduction with large pointed buds of a clear rose pink, earried on long stems.

Price: 4 in. pots, $75 \mathrm{c}$ each; $\$ 7.50$ per 12 .

MI-LADY. A new red rose; buds large and pointed; fragrant, robust and free-flowering. Price: 4 in. pots, $75 \mathrm{c}$ each; $\$ 7.50$ per 12 .

RED MY MARYLAND. A new red rose, very fragrant and a continual bloomer.

Price: 4 in. pots, $\$ 1.00$ each; $\$ 10.00$ per 12 .

SUNBURST. Apricot, shading to primrose yellow at the edge of petals; the flowers are large, full, and perfectly formed.

Price: 4 in. pots, 50c each; $\$ 5.00$ per 12 .

MRS. ARON WARD. Color a distinct shade of Indian yellow, which, as the flower expands, shades lighter toward the edges.

Price: $21 / 2$ in. pots, $25 \mathrm{c}$ each; $\$ 2.50$ per 12 . 4 in. pots, $40 \mathrm{c}$ each; $\$ 4.00$ per 12 .

DOUBLE KILLARNEY. Color similar to Pink Killarney, with large, full, double flowers. A sturdy grower.

Price: 21/2 in. pots. 25c each; $\$ 2.50$ per 12 . 4 in. pots, 35c each; $\$ 3.50$ per 12.

JONKHEER J. L. MOCK. This rose is the best of the La France type, the flowers are borne on long, stiff, erect stems; color, deep imperial pink, outer petal silvery rose white; highly perfumed. Well-rooted plants.

Price: 3 in. pots, $40 \mathrm{c}$ each; $\$ 4.00$ per 12 .

$2 \frac{1}{2}$ in. pots, 30c each; $\$ 3.00$ per 12 .

SINGLE RED CHEROKEE. Another valuable addition to this well-known family.

Price: 5 in. pots, $75 \mathrm{c}$ each; $\$ 7.50$ per 12 .

CRIMSON CHEROKEE. A new addition to the Cherokee's.

Price: $\$ 1.00$ each.

GAINSBOROUGH. A new rose. Pure fleshpink, very full and fragrant. One of the best climbers.

Price: $50 \mathrm{c}$ each.

MELODY. Deep saffron yellow, with primrose edges.

Price: $\$ 1.50$ each.

YOANNE WESSERHOFF. A very hardy rose; color a rich yellow; buds long and pointed beautiful texture; very free.

Price: $50 \mathrm{c}$ each.

\section{ROSES}

We can supply the following roses in standard or tree form. They are budded on single stems three to five feet from the ground. Price $\$ 1.25$ each, except where stated otherwise:

Betty-Red gold overspread with golden yellow.

Price: \$1.50 each.

Mildred Grant-Ivory white, flushed pale peach. Price: $\$ 1.50$ each.

Pink Cherokee-Beautiful single clear pink. Price: \$1.50 each.

Honorable Ina Bingham-A matchless pink. Price: $\$ 1.50$ each.

Lyon-Pink at edge of petals. Center coral red, shaded chrome yellow.

Price: $\$ 1.50$ each.

The following are $\$ 1.25$ each.

Bride-One of the best white roses.

Belle Siebrecht-An unusual pink rose of recent introduction.

Baroness Rothschild-Shell pink. Exquisite shade and fragrant.

Cecil Bruner- A pink babr-rose.

Frau Karl Druschki-Pure snow white. One of the best white roses in cultivation.

General Jacqueminot-Rich velvety crimson.

General MeArthur-Beautiful crimson scarlet. Thrifty grower.

Gruss Au Tepletz-Fine velvety scarlet. Con tinuous bloomer.

Glorie De Margotten-Brilliant shade of red. Strong grower.

Hugh Dickson-Velvety crimson, shaded scarlet.

Kaiserine Augusta Victoria-Flowers pure white.

La France-Delicate silvery rose-shaded pink.

Madame Host-Canary yellow. Flowers produce for a long period.

Marie Von Houtte-White, slightly tinged yellow.

Madame Testout-Bright satiny pink. One of the best.

Mrs. John Lang-Soft pink. Large.

Marechal Niel-Beautiful deep jellow.

Pink Cochet-Fine long-pointed buds.

Papa Gontier-Bright cherry red.

Perle Des Jardines-Deep canary yellow. Very large and full.

Paul Neyron-Deep carmine. Very fragrant.

Rainbow-Coral, mottled with crimson.

Reve de Or-Coppery yellow or rose buff.

Soleil de Or-Orange yellow shaded with copper and red.

Ulrich Bruner-Bright clear red.

Wm. Allen Richardson-Fine orange yellow, apricot center. 


\section{ROSE DEPARTMENT Standard Varieties}

\section{BUSH ROSES}

These roses that are offered are thrifty, welldeveloped, two-year-old, field-grown plants. Price $35 \mathrm{c}$ each, except where stated otherwise:

Bride-One of the best whites.

Countess Riza du Parc-Bronze rose, sweetly perfumed.

Eliza Sauvage-Pure snow white.

Glorie Lyonnaise-White, tinted yellow.

Grace Darling-Pink, tinted white.

Henry Martin-(Moss)-Deep rosy carmine.

Glorie de Dijon-Salmon and yellow.

Madame Falcot-Coppery yellow.

Mrs. Sherman Crawford-Deep rosy pink.

White La France-Pure white, shading to light rose.

My Maryland-One of the best pinks.

Wm. Shaen-The purest pink.

Hon. Ina Bingham-A delightful pink.

White Killarney-Pure white. Exceedingly strong grower.

Bridesmaid-Delicate pink.

Dr. Grill-Clear buff pink.

Rainbow-Deep coral pink mottled with crimson.

Pink Cochet-Beautiful pointed buds.

Maria Van Houtte-White, shading to yellow.

Papa Gontier-Bright cherry red.

Perle des Jardines-Fine canary yellow.

Sunset-Rich saffron and orange.

White Cochet-Vigorous grower.

Belle Siebrecht-An unusual pink.

General McArthur-Dazzling erimson scarlet.

Kaiserine Augusta Victoria-Flowers pure white.

Killarney-A bright carmine pink. Strong grower.

La France-Delicate silvery rose, shaded pink.

Madame Testout-Clear delicate pink. Perpetual bloomer.
American Beauty-Large deep pink, shaded carmine.

Frau Karl Druschki-Pure snow white. Very long buds.

Paul Neyron-Deep carmine. Very fragrant.

Prince Camille de Rohan-Rich, dark, velvety crimson.

Ulrich Bruner-Bright clear red. A profuse bloomer.

J. B. Clark-A scarlet-shaded crimson. Price: $50 \mathrm{c}$ each.

Lyon-Pink at edge of petals; center coral red, shaded chrome yellow.

Price: $75 \mathrm{c}$ each.

Hugh Dickson-Brilliant velvety crimson.

Dean Hole-Silvery carmine, shaded salmon.

La France of $89-$ Fine scarlet.

\section{CLIIMBING ROSES}

Beauty of Glezenwood.

Climbing K. A. Victoria

" Bridesmaid

“ C. Testout

“ Papa Gontier

“ Single Cherokee

“ Dorothy Perkins

" Madame A. Carrier

" Pink Cherokee

" Crimson Rambler

" White Banksia

"Yellow Banksia

" Perle des Jardines

" Cecil Bruner

“ Souvenie De Wootton

" Double Cherokee

“ Glorie De Margotten

“ Gruss au Tepletz

" Reve de Or

" Belle Siebrecht

“ Niphetos
"The man who always does most says the least. Your good works will bless humanity long after you have said 'Good Night.' Your work is always a source of inspiration to me, and I am continuously wondering "What will he accomplish next?'"-Col. G. B. Brackett, Pomological Chief U. S. Dept. of Agriculture, Washington, D. C.
"While I have long been impressed with your work, I am now overwhelmed with the vast amount of good which you have been able to accomplish. I respect your work above all that has ever been done for horticulture."-Prof. Wm. B. Alwood, Virginia College and Experiment Station.

By Dr. L. H. Bailey, professor of botany in Cornell University, New York: "It is an honor to California that Luther Burbank is its citizen. He is all that he has ever been said to be, and more." 

Sıandard Varieties

CHAMEROPS. Very hardy fan-leared palms, readily recognized by the hairy trunks and very lender leaf stalks.

Price: 5-6 ft., 75e and \$1.00 each.

5. $-6 \mathrm{ft} ., \$ 1.00$ and $\$ 5.00$ each.

PHOENIX. (Ormamental Date Palm). The most widely-planted palm in California.

Price: Accorting to size. $\$ 3.00$, $\$ 3.50$ and $\$ 4.00$ each.

WASHINGTONIA. Fan-leaver palm of tall growth, leaf stalks very spiny; rigorous grower.

Price: 2-3 ft., $\$ 1.00$ each

3-4 ft., \$1.50 each.

$5-6$ ft., $\$ 4.00$ each.

KENTIA. One of the finest palms for indoor decorative purposes.

Price: According to size.

Potted, 3 in. 50c each.

Potted, 4 in., $75 \mathrm{c}$ each.

Potted, $T$ in., $\$ 3.50$ each.

Potted. 8 in., \$5.00 each.

Potted, 9 in., $\$ 9.00$ and $\$ 10.0$ each.

DRACENAS. Tropical-looking plints with sтот-shaped leaves. Tery ormamentil. Good for street planting.

Price: $11 \frac{2}{2}-2 \mathrm{ft}$. . $75 \mathrm{c}$ each.

$$
2-3 \mathrm{ft} . \text {. } \$ 1.25 \text { each. }
$$

3-4 ft., \$1.7.5 and $\$ 2.00$ each.

FERNS, ETC.

Conservatory an Parlor Decorative Plants.

ASPARAGU'S. Plumosis. Pot, 35c and 50c. Srrengerii. Pot, 50e and 75c.

ASPIDISTRA IURIDA. This plant is one of the most hardy for house decoration, has large dark green foliage.

Price: \$1.50. \$2.50. \$3.50 and \$5.00 each.

CYCLAMEN. Chaming plants with beautiful foliage and richly-colored flowers.

Price: $\$ 1.00, \$ 1.50$, $\$ 2.50$ and $\$ 3.00$ each.

JAPANESE HANGING FERN BALLS. Price: $50 \mathrm{c}$ and $75 \mathrm{c}$ each.

NEPHROLEPIS BOSTONIENSIS. (Boston Fern). Grows well and improves in size where most all other ferns fail.

Price: $\$ 2.00, \$ 2.50, \$ 3.00, \$ 4.00, \$ 5.00, \$ 7.50$. $\$ 9.00$ each.

NEPHROLEPIS ROOSEVELT. One of the late introductions. Same price as Boston.

NEPHROLEPIS WHITMANII.

Price: $75 c, \$ 1.25$ and $\$ 2.00$ each.

NEPHROLEPIS SCOTTII.

Price: $75 \mathrm{c}, \$ 1.25$ and $\$ 2.00$ each.

\section{MSCELLANEOTS BORDER AND BEDDTYG} PLANTS

(For Burbank Profuctions, See Ante).

BEGONIA VERNON. Foliage deep olive green. edged with bronzed purple. flowers bright red and pink; makes a fine borker or bet? Price: $\$ 1 .{ }_{0}$ per doz.

CAIIPANUIA. TTell-known hardy biennials bearing numerous bell-shaped flowers; fine for plant'ng in beds or mixed borders. Strong field-grown plants.

Price: 25c each ; $\$ 2.50$ per doz.

CANNAS. Very attractive plants with large green and bronze toliage. The flowers arp prołuced on tall stalks, appearing from eqrly spring until late in the fall. Price: 20e each; $\$ 2.00$ per doz.

CINER $\triangle$ PIA. Exce!lent for rlanting uniler the shade of large trees with dense masses of various colored flowers. Pot grown.

Price: $25 \mathrm{c}$ each; $\$ 2.50$ per doz.

DAISIES. Double, all colors. Price: 35c per doz.; $\$ 3.00$ per 100 .

DELPHINIUM. A renarkably show cliss of tall-growing olants. proluciug spikes of rarious sharles of blue flowers. Fine for mixerl borders. Strong plants. Price: $25 \mathrm{c}$ each; $\$ 2.50$ per doz.

FUCHSIAS. These plants require a good rich soil and partial shade; can be grown as bush or traired along the fence or side of house. Price: 25c and 35c each.

COIDEN FEATHER. Makes a fine rellow border.

Price: 35e per doz.; \$2.50 per 100.

HELIOTROPE. A half-hardy shrub; flotrers very fragrant.

Price: 20c each; \$2.00 per doz.

IOBEIIA. Dwarf blue; useful for borders or window box.

Price: 3̌e per doz; $\$ 3.00$ per 100 .

MARGUERITS. (Mrs. Saunders). Double-flow ering, hordy. perennial shrub remaining in bloom all the year round.

Price: 25c each; $\$ 2.50$ per doz.

PANSIES. Best mixed prize strain.

Price: 50c per doz.; $\$ 3.50$ per 100.

SALVIA. (Searlet Sage). A standard bedding plant and one of the handsomest summer and autumn flowering plants.

Price: $\$ 1.00$ per doz.

STOCKS. Very popular annuals, producing touble and single fragrant flowers.

Price: 25e per doz.
"Mr. Burbank's greatness, and the magnitude of the value of his achievements are recognized the wcrld over by men best capable of understanding and appreciating both the man and his work."-Congressman E. A. Hayes.
"To Luther Burbank has been granted the knowledge, supreme beyond other men, of the susceptibility of plants to vary under the influence of new environments, delicate manipulation and intelligent direction."-Scientific American. 


\section{The Luther Burbank Company San Francisco. C al. U.S.A.}

\section{HOW TO ORDER}

Wherever it is possible to do so, use the order blank.

Fill out all the information that the blank spaces call for.

Be sure to write your name plainly. Give postoffice where you receive your mail, including County name. State plainly the town or point where you receive your freight.

Give the name of the Railroad or Express company from which you receive your freight. State whether to ship by freight or express. In the absence of specified instructions, we shall use our judgment.

Usually orders will be shipped by freight unless otherwise specified. An exception to this rule will be where the package is small, when it may be shipped by express.

You will be notified of shipment. Allow a sufficient length of time for the package to arrive, and then if it does not arrive notify the railroad or express company, showing the bill of lading. Also notify us by mail and we will send a tracer after it.

We are not responsible in any manner after we have delivered the shipment in proper condition to the carrier. We will do all in our power, however, to straighten ou any difficulty. All claims for defective or damaged goods must be made immediately upon receipt of same.

All remittances must be either postal orders, bank drafts or certified checks, properly made out to this company.

Unless specially indicated otherwise all packing and freight or shipping charges are to be borne by the purchaser. Only actual cost of packing is charged and every endeavor is made to restrict such costs to the minimum consistent with proper packing. A minimum packing charge of 25 cents for 1 up to 5 fruit trees and 5 cents per fruit tree additional up to 10 trees should be remitted with order. As all other packing charges vary, actual cost of packing to be paid by purchaser on notification.

\section{Our Other Catalogs}

We have other catalogs in preparation, nolably our seed book for 1914. As the Luther Burbank Company now has the most complete stock of seeds-both flower and vegetable - in the West, every person interesied in either will want this catalog.

We again call your attention to the fact that genuine Burbank seeds must be purchased from this company and must carry our trade mark seal. They are not procurable elsewhere. None is sold in bulk. Look for the Burbank seal on every packet you buy.

By writing to us now for our 1914 seed catalog, your name will be listed, insuring an early receipt.

\section{OUR GUARANTEE}

We guarantee the seeds, plants or trees sold by this Company true to name, and will replace any that may prove otherwise through a possible error, or will refund the original purchase price. Our liability upon any article sold is limited to the amount of the original purchase price, and all sales are made with this understanding.

\section{THE LUTHER BURBANK COMPANY}




\section{The Luther Burbank Company} San Francisco. Cal. U.S.A.

\section{Index to Fruits}

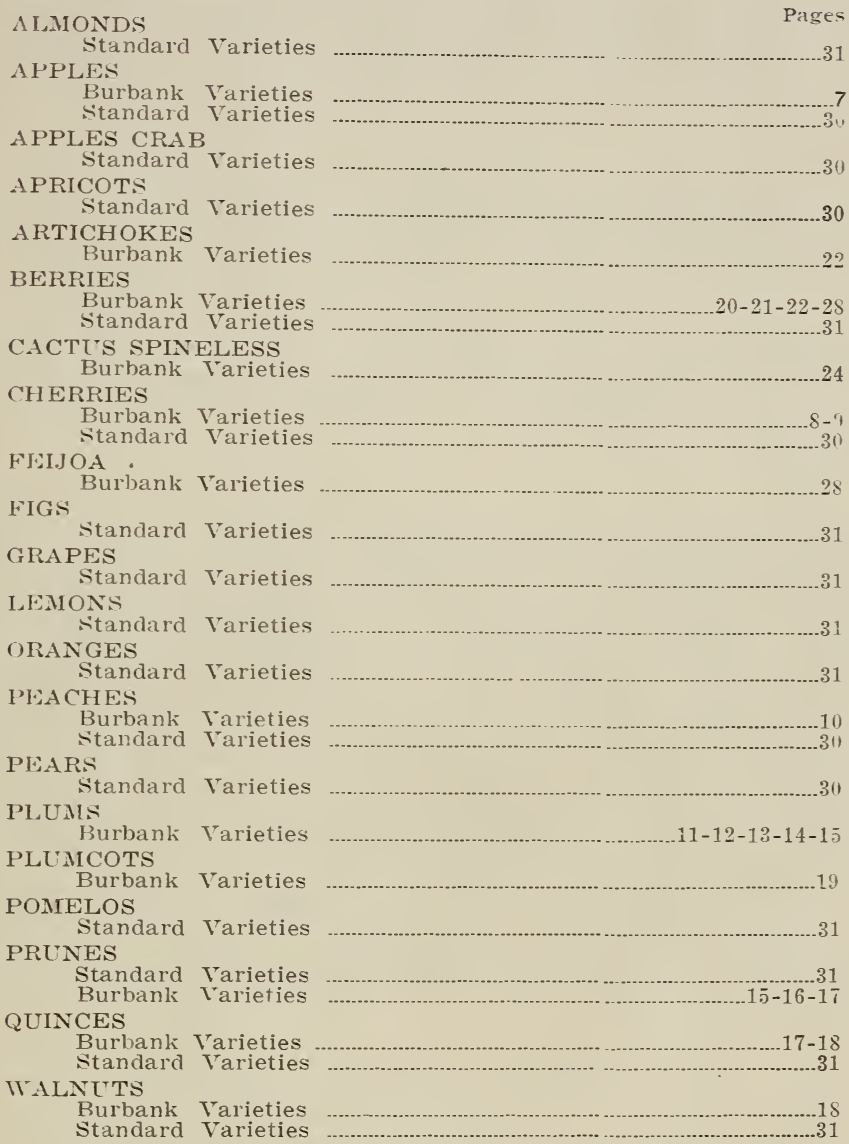

Standard Varieties

Pages

APPLES

Burbank Varieties

standard Varieties

APPLES CRAB

Standard Varieties

APRICOTS

Standard Varieties ..............................................................................3

ARTICHOKES

Burbank Varieties BERRIES

Burbank Varieties

standard Varieties

CACTIS SPINELESS

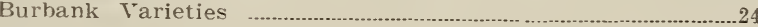

CHERRIES

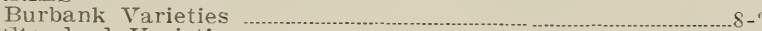

FEIJOA

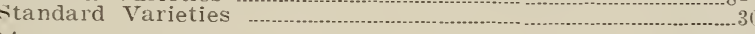

Burbank Varieties

Standard Varieties GRAPES

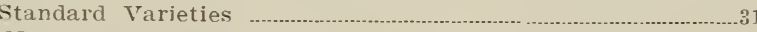

LEMONS

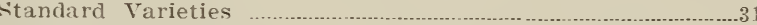

ORANGES

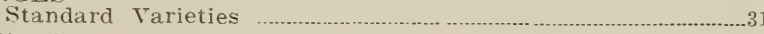

PLACHES

Burbank Varieties

PEARs

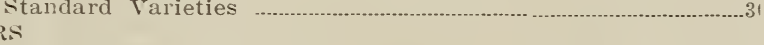

PLUMS

S

PLUMCOTS

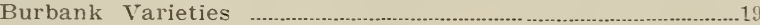

POMELOS

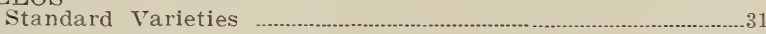

PRUNES

Standard Varieties
Burbank Varieties

QUINCES

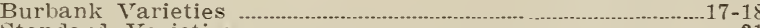

Standard Varieties .......................

WALNTTS

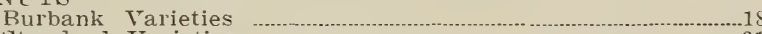

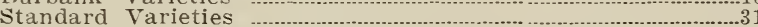

Index to Ornamental Department

(Exclusive Burbank Productions)

ROSES

SHASTA DAISIES

$26-27$

TREES AND SHRUBS

PLANTS AND FLOWERS

Standard Varieties

EVERGREEN TREES AND SHRUBS ……….............................32-3:

CLIMIBING AND TRAILING PLANTS …_.............................................33

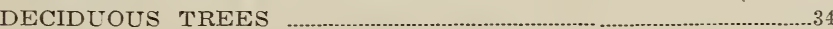

DECIDUOUS SHRUBS ...

ROSES

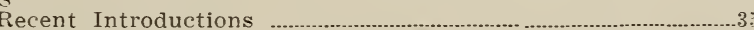

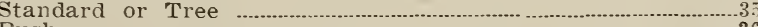

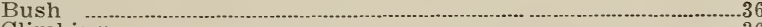

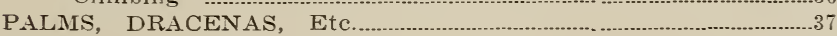




\section{Our New San Francisco Headquarters}

With the establishment of new headquarters at Market and Beale Streets, San Francisco, the Luther Burbank Company enters the general seed and nursery field with every improved facility for meeting the general demand in these two lines.

The ground floor of their new building in San Francisco is devoted to the sales rooms, a continuous exhibit of original Luther Burbank creations and the most complete lines of seed and nursery productions in the West. The executive offices are located on the second floor.

Owing to the increased interest in original Burbank creations, it is planned to maintain a constantly changing Burbank horticultural exhibit in the new headquariers. As the ripening periods arrive, specimens will be brought from the Company's various Proving Grounds, Nurseries and Seed Farms and attractively displayed in the store. On account of the extensive window space on both Market and Beale Streets and the unique interior arrangement, this store is sure to prove one of the great horticultural attractions in the United States. In reality it will be a continuous Burbank Exposition. As an adjunct of this exhibition, a new feature will be introduced, the showing of Burbank novelties by direct color photographs in connection with stereopticon projections.

A service department is also installed, at the head of which are men of wide experience in practical horticulture. Their advice, which will be given gratuitously, extends to every phase of the growing of fruits and flowers, as well as the difficult problems in landscape gardening.

None the less instructive will be the display of original Luther Burbank Spineless Cactus. A visit to this store by anyone interested in practical horticulture or floriculture cannot help but prove of tremendous interest and practical value. The comfort and convenience of all visitors has been provided for in every way, especially out of town visitors, by the installation of a reception bureau. You are cordially invited to visit us in our new business home.

\section{The Luther Burbank Company}

General OfFices

BURBANK BUILDING, MARKET AND BEALE STREETS

SAN FRANCISCO, CALIFORNIA, U. S. A. 



\section{A MESSAGE}

MNY new trees, plants and seeds are grossly misrepresented by a few dealers who trade on the reputation of reliable firms, often doing a thriving business by selling trees and plants in localities where they very well know that they cannot thrive; this and the substitution of inferior or wholly worthless trees or plants under the name and reputation of good ones has been, and is now being carried on persistently and systematically by several parties who victimize those who deal with them by trading on the reputations of reliable firms and good trees.

An especially cruel form of this is the persistent pushing of the Spineless Cactus, Crimson Winter Rhubarb and other tender plants for cold climates, which cannot live where the ground freezes an inch in depth.

It should be the duty and privilege of every good citizen to aid in exposing and routing all who are obtaining money under these false pretenses.

Having been in business almost forty years, millions of trees and plants raised in my establishment are now bearing fruit, not only in the Western United States, but everywhere on earth where the sun shines and trees can be grown. Does this forty years' record of just dealing mean anything, and is it surprising that such a reputation should be worth trading on? Counterfeit coins are not counterfeited-it is the genuine ones that are misrepresented.

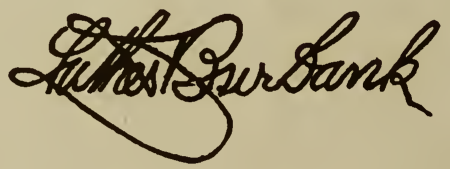

